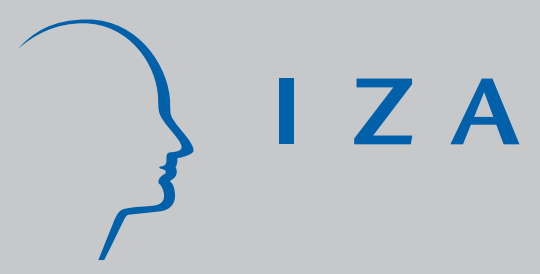

IZA DP No. 2649

Integrating Severely Disabled Individuals into the Labour Market: The Austrian Case

Brigitte Humer

J ean-Philippe Wuellrich

J osef Zweimüller

February 2007 


\title{
Integrating Severely Disabled Individuals into the Labour Market: The Austrian Case
}

\author{
Brigitte Humer \\ Upper Austria University of Applied Sciences \\ Jean-Philippe Wuellrich \\ University of Zurich \\ Josef Zweimüller \\ University of Zurich, CEPR, CESifo and IZA
}
Discussion Paper No. 2649
February 2007

IZA
P.O. Box 7240
53072 Bonn
Germany
Phone: +49-228-3894-0
Fax: +49-228-3894-180
E-mail: iza@iza.org

\begin{abstract}
Any opinions expressed here are those of the author(s) and not those of the institute. Research disseminated by IZA may include views on policy, but the institute itself takes no institutional policy positions.

The Institute for the Study of Labor (IZA) in Bonn is a local and virtual international research center and a place of communication between science, politics and business. IZA is an independent nonprofit company supported by Deutsche Post World Net. The center is associated with the University of Bonn and offers a stimulating research environment through its research networks, research support, and visitors and doctoral programs. IZA engages in (i) original and internationally competitive research in all fields of labor economics, (ii) development of policy concepts, and (iii) dissemination of research results and concepts to the interested public.
\end{abstract}

IZA Discussion Papers often represent preliminary work and are circulated to encourage discussion. Citation of such a paper should account for its provisional character. A revised version may be available directly from the author. 


\section{ABSTRACT}

\section{Integrating Severely Disabled Individuals into the Labour Market: The Austrian Case*}

We study the impact of the Austrian Employment Act for the Disabled which grants extended employment protection, requires a hiring quota for firms, and subsidizes the employment of severely disabled (SD) workers. Using a large sample of eligible individuals we compare workers before and after acquiring legal SD-status. Unsurprisingly, we find that holding SDstatus is associated with lower employment and earnings. However, workers holding a job when acquiring legal SD-status have substantially better subsequent employment prospects after SD-award than before. In contrast, workers who do not hold a job at the date of SDentry do dramatically worse after SD-award than before. This suggests that employment protection legislation places substantial firing costs on firms and has a major impact on the decisions of firms to hire disabled workers.

JEL Classification: J14, J71, K31

Keywords: disability, employment protection

Corresponding author:

Josef Zweimüller

University of Zurich

Institute for Empirical Research in Economics

Bluemlisalpstrasse 10

$\mathrm{CH}-8006$ Zurich

Switzerland

E-mail: zweim@iew.unizh.ch

\footnotetext{
${ }^{*}$ We thank Dr. Hofer, Ministry of Social Affairs, Vienna, and Dr. Konrad, Bundesrechenamt Vienna, for giving us access to the data. We are grateful to Rafael Lalive, Andreas Kuhn and Oliver Ruf for many discussions on the subject. This paper was funded by the Austrian National Bank ("Jubiläumsfonds"), research grant 12327.
} 


\section{Introduction}

We examine the impact of the Austrian Employment Act for the Disabled (EAD, Behinderteneinstellungsgesetz) which is a major program to foster the integration of severely disabled individuals into the Austrian labor market. This program has been strongly expanded since the early 1990s increasing from 1.2 percent of the employed (15-64) population in 1990 to 2.4 percent in 2005. During the same period, real government expenditures to support this program have increased by 258 percent. Our empirical analysis studies the impact of this program on employment prospects and earnings of severely disabled beneficiaries. It also addresses the question whether employment protection legislation of the EAD has had an impact on employment rates; and whether the increased policy efforts of the Austrian government during the 1990s were successful in improving labor market outcomes of severely disabled individuals.

Studying the effects of disability policies on the labor market outcomes of disabled workers is of obvious importance for social policy. First, a severe mental or physical disability signficantly raises the risk of poverty and social exclusion and holding a job signficantly decreases these risks. As a result, a growing consensus has emerged among policy-makers that supporting disabled workers in finding and keeping a job are the most effective means of improving their lives. Second, in recent years many countries have undertaken major policy reforms aimed at integrating disabled individuals into the labor market (OECD, 1992, 2003) often involving substantial government funds. A profound knowledge of the impact of these various policies is essential for knowing which programs works and which do not. Finally, the Austrian EAD is work-related programme aiming at activating disabled workers. The particular policy-mix involving the worker, the firm, and the state may be a potentially interesting case study potentially valuable in other contexts.

The Austrian EAD contains three main regulations. First, severely disabled (SD) workers enjoy particularly high employment protection compared to non-disabled workers. ${ }^{1}$ Once hired, the severly disabled worker can only be fired upon approval of a government committee representing the disabled workers' interests (Behindertenausschuss). While this does not mean that a SD workers has full employment protection these rules place disproportionately high firing costs on firms. Second, firms are required to meet an employment quota for SD workers: Per 25 non-SD workers one SD worker has to be hired. Non-compliance with this rule leads to a tax, which in 2006 amounts to 206 Euros per (non-hired) disabled worker. This is a non-negligible amount, roughly equal to 10 percent of the median wage (or 6 percent of total labor cost) of an Austrian worker. Third, firms and workers get financial support to

\footnotetext{
${ }^{1}$ Employment protection for non-disabled individuals is relatively low in Austria, compared to other countries. A private-sector worker can be fired after an advance notice of 3 months with special rules for older employees.
} 
ensure that the disabled workers can keep their job (or get a new one). For instance, firms get wage and training for hiring and keep an precarious job for the disabled workers. Investments necessary to accomdoate the workplace for the purposes of a disabled worker are paid by the government. Workers are supported by job assistance and get subsidies for retraining etc. This implies that Austria is quite different from the U.S. where the Americans with Disabilities Act (ADA), implemented in 1990, obliges firms to adopt workplaces for the needs of disabled workers but these firms typically do not get financial support for such investments. While several studies have shown that the ADA had negative employment effects, a recent study by Jolls and Prescott (2004) attributes these detrimental effects to the firms' costs to meet the requirement of "reasonable accommodations" for disabled employees. Since such costs are small in Austria, any effects that show up in our study have to be attributed to hiring and firing costs of SD workers.

Our paper goes beyond the existing literature in various respects. First, our data set is very large and provides detailed longitudinal information on the work and earnings history of disabled individuals in Austria. This is different from many previous U.S. studies which have relied on repeated cross-sectional data (such as the CPS). In particular, our data allows us to follow the worker 5 years before and 5 years after acquiring the disability status. Second, our measure of severe disability is an objective assessment of the health status of a worker. (To acquire the legal SD-status, individuals have to formally apply and undergo a medical check where an independent doctor has to diagnose a severe disability for applicant implying a degree of work incapacity of 50 percent or more). This implies that our study is less likely to suffer from measurement error of the disability variable. This is important as previous studies for the U.S. - which have relied on self-reported measures - have found that ADA effects are not robust to different measurement concepts of disability status. Third, our data set is large enough to look in detail at heterogenous SD-effects on labor market outcomes. This is potentially important because severely disabled indivduals are a rather heterogenous group. In particular, we will focus on the question whether this effect differs by age and sex, whether it differs by employment status at SD-entry and whether it has changed during the 1990s as a result of increased government efforts to improve the performance of severely disabled individuals in Austria.

Our findings are as follows. First, we find that labor market outcomes get significantly worse two years before a worker acquires the "severe disability status" (SD status) which formally subjects the disabled worker and his or her (potential) employer to the rules of the Austrian EAD. Second, we find that employment effects are long-lasting and continue beyond the acquistion of the legal SD status. However, these detrimental employment effects are concentrated among older $(45+)$ workers whereas the employment prospects of younger workers 
improve after acquiring SD status. We also find, unsurprisingly, that wages of all groups fall after entering SD-status. Third, we find that employment protection legislation has a strong impact on employment patterns of different groups of workers. Workers who are employed at the date of SD award (the majority) enjoy significantly better employment prospects after SD entry than before. In contrast, workers who are non-employed at the date of SD award suffer from very strong, negative employment effects. This suggests that employment protection legislation of the Austrian EAD places substantial firing costs on employers and strongly affects hiring decisions.

The paper is organized as follows. In the next section we briefly review related literature. In section 3 we discuss the institutional environment in Austria and its incentives for workers and firms and potential implication for employment and earnings. Section 4 discusses the data and section 5 present descriptive evidence. Section 6 presents our main results. Section 7 concludes.

\section{Related literature}

Recent studies on the impact of disability on labor market outcomes and policies to improve the labor market performance of disabled individuals have concentrated on the labor supply impact of disability insurance. Bound and Burkhauser (1999) provide a survey for the relevant U.S. literature. Baldwin and Johnson (2000) provide evidence on the extent of discrimination of disabled individuals in the US. They document that disabled individuals have lower wages and much worse employment prospects that non-disabled workers. Burkhauser et al. (2000) show that disabled individuals did not benefit as much as the non-disabled from the boom in the 1990s. Burkhauser and Daly (1998) compare the situaton of disabled and non-disabled individuals in the USA and in Germany. It turns out that the disability earnings-penalty is much higher in the US and that relative employment rates are more favorable for the disabled in Germany.

More recent and closely related studies have looked how the „Americans with Disabilities Act" (ADA) which was implemented in the U.S. in 1990. As mentioned above the ADA requires firms to provide workplace accomodations for disabled individuals. Moreover, disabled individuals are subject to employment protection. DeLeire (2000) was among the first studies to evaluate the labor market outcomes of the ADA. He finds negative employment effects that start already at the year of introduction of the ADA and continued up to the mid 1990s for disabled men. Employment of disabled fell by more than 7 percentage points but wages of employed workers remained roughly constant.

The study by Acemoglu and Angrist (2001) provides a more detailed analysis by age and 
sex and broadly confirms these findings. The impact of ADA on wages appears insignificant whereas employment effects are negative. While the negative employment effects may partly due a rise in the number of disability benefit recipients, the introduction of the ADA is also a likely cause. Further support for this conclusion comes from the fact that negative employment effects are stronger in medium sized-firms (small firms were exempt from the ADA) and in states with more discrimination charges.

Jolls und Prescott (2004) challenge the conclusion that negative employment-effects are due to employment protection legislation. They use state-level variation in prior to the introduction of the ADA and show that these effects are more likely due to the costs to firms of accommodating the workplace to the need of disabled workers. ${ }^{2}$ Kruse and Schur (2003) explore the sensitivity of previous ADA-results with respect to the measurement of disability. Using a measure that is more closely related to the definition of disability than previous studies they find positive ADA employment effects. Beegle und Stock (2003) use state-level variation in anti-discrimination laws prior to $\mathrm{ADA}$ and find that disability discrimination laws are associated with lower relative earnings but not with lower relative employment rates of the disabled. Jolls (2004) studies whether lower post-ADA employment levels might have resulted from increased participation in educational opportunities. She finds that disabled individuals who were not employed after the introduction of the ADA were more likely than their pre-ADA counterparts to be enrolled in education.

The literature outside the U.S. is comparably scarce. Kidd et al. (2000) show that disabled individuals in the UK have a much worse labor market performance than the non-disabled both in terms of employment and labor earnings. A closely related study by Bell und Heitmüller (2005) study the effects of the 1996 Disability Discrimination Act in the UK and finds no or a negative impact on the employment rate of disabled people. They conclude that low take-up of financial support, low levels of general awareness about the Act among disabled people and employers, and limited knowledge about the true costs of required adjustments are the most plausible reasons for this result.

In a study of the EU commission (2001) points to the double penalty of disability as, in addition to their physical or mental handicap, are typcially also less well educated. Daly (1997) analyzes the quantitive effects of this double penalty for Germany and concludes that existing policy measures are insufficient for the disabled to succeed on the labor market. Wagner et al. (2001) analyze employment legislation for severly disabled workers in Germany which obligate

\footnotetext{
${ }^{2}$ Burkhauser et al. (1995) investigate the impact of workplace accomodation on job security of disabled workers and find that those accomodations have a positive impact on the duration of employment relationships. They further emphasize that already in 1978 a larger fraction of disabled workers benefitted from workplace accomodations.
} 
firms above 15 employees to hier disabled workers and yield inconclusive results. Lechner and Vasques-Alvarez (2003) use data from the German socio-economic panel (GSOEP) to assess the impact of disability on the success of disabled individuals on the labor market. They find that the chances of disabled individuals to hold a regular job are 9.6 percentage points lower and their earnings are 16 percent lower than those of the non-disabled. Lalive et al. (2007) evaluate the firms' employment obligation of the Austrain EAD and find significant effects of this rule on the demand for disabled workers in Austria. Their estimates imply that roughly 12 percent of disabled workers are hired as a result of this obligation. ${ }^{3}$

\section{The institutional framework}

The main legal instrument of the Austrian government to enhance the labor marekt success of severely disabled individuals is the Employment Act for the Disabled (EAD, Behinderteneinstellungsgesetz). The EAD was implemented in 1969. ${ }^{4}$ The law provides a defnition of the severe disability (SD) status and how an individual can acquire this status. The access to this status is extremely restrictive and strictly monitored by government institutions. In order to get entitled to the SD-status, the disabled individual has to file an application to the Austrian Federal Welfare Office which starts a formal procedure that asesses whether or not the applicant is eligible to this status. ${ }^{5}$ The SD-status is finally awarded to the applicant if a medical expert of the federal welfare office diagnoses a degree of disability due to a physical, mental, intellectual or sensuous disorder such that the work capacity of the applicant is reduced by at least 50 percent. The SD-status cannot be recalled by the SD-beneficiary unless a new expertise assesses that the disabled's situation has improved such that the degree of disability reduced to less than 50 percent. In that case, the former SD beneficiary disqualifies for the SD status. In particular, the SD individual herself cannot recall this status. This rule protects the disabled worker from being forced by her employer to recall the status. In what follow, "disabled" workers are defined as individuals holding the legal SD-status.

\footnotetext{
${ }^{3}$ Concerning empirical evidence for Austria, most studies are descriptive and based on survey data. Badelt and Österele (1993) dicuss the labor market situation of disabled individuals in Austria. For a more recent account of the current problems of disabled individuals on the Austrian labor market see BMSG (2003). Dyk et al. $(2002,2004)$ concludes on the basis of firm surveys that employment protection is a major cause for the firms' reluctance to hire disabled workers.

${ }^{4}$ There are two other laws at the federal level that exclusively refer to the disabled: The Federal Disability Act (Bundesbehindertengesetz) and the Act on Equal Opportunities for Disabled (Bundesbehindertengleichstellungsgesetz). These acts refer to all aspects of social life and are not specific to labor marekt participation. Hence these acts are not of direct concern in the present context.

${ }^{5}$ Only Austrian nationals or nationals of the European Economic Area can apply. In addition, students and retirees are excluded.
} 
An important rule is that SD-status can be acquired if an individual is, in principle, available for the work (even if currently inactive). Individuals who are permanently out of the labor force (or currently unavailable for the labor market) are not entitled to acquire SD-status. This latter group includes individuals enrolled in formal education, individuals beyond age 65 , early retirees receiving a permanent disability or early retirement benefit, and individuals whose kind or severeness of disability does not allow them to work.

Figure 1 presents the evolution of the number of workers holding SD status over the period 1975 to 2005 . The number of individuals holding SD status was slightly declining until 1990 when about 1.2 percent of the Austrian work force (or 40,000 individuals) were holding this status. During the 1990 the program increased dramatically. By the year 2005, the stock of SD individuals has more than doubled amounting to 2.4 percent of the Austrian work force.

Figure 1

The benefits of SD status are regulated in the Austrian EAD. The EAD is based on three pillars. The first pillar is the obligation of firms to hire disabled workers. More precisely, firms are obliged to hire one disabled worker per 25 non-disabled workers. If a firm does not comply with this obligation, a monthly non-compliance tax (Ausgleichstaxe) has to be paid for each mandatory SD-job that has not been filled. This tax goes to the earmarked noncompliance tax fund (Ausgleichstaxfonds), which is used to cover government expenditures for wage and training subsidies, workplace accomodations and other measures aimed at promoting employment of the disabled. To account for inflation, the non-compliance tax was gradually increased throughout the 1990s, from $€ 118$ in 1990 to $€ 148$ in 2000. Two important changes with respect to the non-compliance tax took place. On July 1, 2001 the tax was substantially increased by $€ 50$ to $€ 198$ and in 2006 the tax amounted to $€ 206$. Another important policy change took effect on January 1, 1999. Before 1999 firms that over-complied the employment obligation (i.e. hired more SD workers than necessary to fulfill the quota) were subsidized by the amount equal to the non-compliance tax per additional SD worker. On January 1, 1999 this regulation was abolished. The employment obligation is enforced by the Austrian Federal Welfare Office. Based upon information of the social security register, the number of employed non-disabled workers is checked on the first day of a month for every firm. From this information the federal welfare office determines the number of mandatory SD-workers per firm ${ }^{6}$ and charges the tax from non-complying firms.

The second pillar of the Austrian EAD are wage and training subsidies and subsidies

\footnotetext{
${ }^{6}$ There is double-counting for some particularly disadvantaged groups: blind workers, workers depending on a wheelchair, SD workers younger than 19 SD, apprentices, SD workers older than 50 with a work capacity of less than 30 percent, and SD workers older than 55 .
} 
to workplace accomodations, work assistance, occupational retraining or professional development. These subsidies are either paid to employers hiring SD workers or directly to SD individuals. These financial subsidies are financed out of the non-compliance tax fund; the European Social Fund (available since 1995 when Austria joined the EU); and additional funds provided by the Austrian government (available since 2001). In 2006, overall expenditures fostering employment of SD individuals amounted to $€ 160$ Mio., roughly 1800 Euros per SD individual per year. Via the non-compliance tax, the second pillar is a mechanism that redistributes funds from non-complying to complying firms in order to compensate the latter for their effort in employing disabled worker.

Figure 2 shows how real expenditures (at 2005 prices) have increased since the early 1990s. Real expenditures stagnated (and expenditures per capita even fell) until 1996. However, after that date, things changed quite strongly. Between 1996 and 2005 total real expenditures rose by 258 percent and expenditures per SD-individual rose by 70 percent. In 2005 yearly expenditures per SD invididual amounted to 1747 Euros.

\section{Figure 2}

The third pillar of the Austrian EAD concerns increased employment protection of SD workers. Once hired, a worker is subject to a probation period which is currently 6 months. During that period, the employer can fire the SD worker without giving a specific reason. The probation period was originally only one month and was extended in two steps, from one to three months on January 1, 1999 and from three to six months on July 1, 2001. After the probation period, the SD workers can only be fired with the consent of a regional government agency representing the interest of SD workers in that region (Behindertenausschuss). Employment protection also encompasses "wage protection" (Entgeltschutz) meaning the SD worker is not only protected from loosing the job but also from major wage cuts.

\section{Data}

We draw our data from two different administrative sources. The first data set comes from the Austrian Ministry of Social Affairs (BMSG) and covers the universe of individuals that were awarded SD status (Begünstigte/r Behinderte/r) during the period 1987-2005. These data report a disabled individual's (anonymized) social security number, the date when the individual acquired the legal disability status, the date when this status ended (almost entirely either retirement and death), and the extent of the disability. The second data set comes from Austrian social security records (ASSD). These data are provided by the Austrian social security agency ("Hauptverband der österreichischen Sozialversicherungträger") and cover lon- 
gitudinal (earnings and employment) information necessary to assess the old-age social security benefits. Apart from the individual's detailed employment and earnings history, this data set reports a worker's (anonymized) social security number and a limited set of socio-demographic characteristics (such as age, sex, and broad occupation). The ASSD covers universe of private sector workers in Austria over the period 1972 to 2002.

We evaluate the evolution of the disabled's labour market position by looking at data on employment status (employed, unemployed, out of labor force) during a particular baseline date (August 15 of each year). For those who hold a job at this baseline date we use the information on daily earnings available in the ASSD to trace the position of SDs in the earnings hierarchy over time. In particular, we focus on the the SD's earnings relative to median earnings of male private-sector workers. (Appendix A reports the evolution of nominal earnings over the relevant time period 1987-2002.)

In the present context, our data set has various obvious advantages. First, the concept of disability is clearly defined and measurement error (which is potentially important in studies reyling on self-reported disablity) are of no concern in the present analysis. Second, measurement error in earnings and employment status is high-quality information either, because firms and workers are obliged to report to the social security agency and wrong declarations are considered an illegal act. Third, the fact that we dispose of the universe of SD-individuals that were awarded with SD-status during the period 1987-2002 leaves us with rather large samples that lets us estimate the parameters of interest with high precision. Furthermore, the large numbers of observations are helpful when we look for heterogeneity in the effects of SD-status. This is important because SD individuals are a potentially very heterogeneous group.

\section{Descriptive evidence}

Before we start evaluating the impact of SD status on the labor market performance of severely disabled individuals, we examine the extent and composition of the SD inflow. We start by documenting the size and composition of the SD inflow since the late 1980s and ask for the potential reasons for the observed increase in SD awards over time. In a second step, we look at a potential impact on SD award on labor market outcomes. In particular, we will look at how both employment status and daily earnings change during the years before and after certification of SD status.

\subsection{Size and composition of SD inflow}

Figure 3 shows how the inflow into severe disability status (SD) has evolved since the late 1980s. The number of new SD awards was still relatively low in 1987, when this inflow amounts to 
less than 4,000 individuals or roughly 0.1 percent of (or 10 awards per 10,000) of the Austrian workforce. This number was strongly increasing up to the year 1994, when it stayed constant at about 8,000 individuals per year (or 0.2 percent of total employment). The peak was reached in 2002 , when the inflow rate had risen to 0.25 percent of the Austrian work force. In recent years the inflow has been decreasing.

Figure 3

The question is why the number of new SD awards were increasing so strongly during the 1990s. There are two obvious explanatory variables. The first is a change in the age structure of the population and the second is a change in female labor force participation. If demographic changes are such that age-groups with high SD-inflow rates become larger this will result in a larger inflow into SD status even when the propensity to sign up for this status remains constant. Similarly, recent decades have seen a strong increase in labor force participation. If it becomes more common for females to participate in the labor market, there will be larger pool of potential female SD applicants hence SD award rates are likely to rise.

Table 1 examines the age- and sex-composition of new SD-awards over the period 1987 to 2005. In the late 1980 more than 70 percent were males. Since then the percentage males has been constantly decreasing and reached levels slightly above 60 percent in 2005 . Hence the stronger attachment of women in the labor market may be one potentially important factor that contributes to the increase in female SD awards during the 1990s. Table 1 also shows that an even more dramatic change in the composition of the SD inflow has occured with respect to the age of new SD individuals. Whereas less than 30 percent were older than 45 during the late 1980s, individuals aged $45+$ have become the majority by 2005 . While during the 1990 s the age group $45+$ has increased in absolute numbers, this increase is far too small to account for the huge increase in SD inflows that is observed among this group.

\section{Table 1}

Perhaps a more important reason for the large increase in SD inflow is that the system has become more accessible to applicants. One possible indicator for generosity are the number of accepted applications. The increased incidence of severe disabilities in many countries is hard to reconcile with advances in medical treatment and rehabilitation technologies and the seculare trend away from physically exerting work. In constrast, increased disability inflow is often due to the fact that screening processes have been relaxed, in particular with respect to mental illnesses and multiple non-severe ailments. ${ }^{7}$ While information in the BMSG data set

\footnotetext{
${ }^{7}$ For instance, Autor and Duggan (2006) mention that the 1984 reform of the US Social Security Disability Insurance program shifted the focus of screening from purely medical to workplace-functioning criteria. As
} 
on the medical reason for awarding SD status is not available to us, the data report the degree of disability of the applicant awarded with SD status. Table 2 shows that the average new SD beneficiary has become less severely disabled (as measured by the degree of work incapacity at the SD inflow date). At the end of the 1980s, only 46 percent of new beneficiaris had a degree of work incapacity of exactly 50 percent. Around the year 2000 this number has increased to 59 percent. In constrast the percentage SD beneficiaries with a work incapacity larger than 75 percent has decreased from 31 to 23 percent.

Table 2

A major incentive for a disabled worker to apply for SD status is the extended employment protection granted by the Austrian EAD. Tables 3 and 4 report the composition of SD award by employment status at the date of SD inflow and by attachment prior to that date. Figure 3 shows that roughly 70 percent of new SD beneficiaries are employed and the remaining 30 percent are either unemployed (13 percent) or inactive (17 percent) with females and younger SDs are somewhat less likely to be employed and more likely unemployed and/or inactive. Panel B of Table 3 reveals that the average new female SD beneficiary is equally likely employed in more recent cohorts than in previous cohorts whereas the new male SD beneficiary is less likely to be employed. Hence moral hazard behavior as a reason for the increase in SD inflow - in the sense that employed workers are seeking more employment protection in recent years - can be ruled out.

An interesting issue is how the soaring SD inflow of the 1990s has affected the skill composition of the inflow. While our data do not directly report workers' skill, we can infer worker quality from the previous work history, in particular whether a worker is strongly attached to the labor market (as measured by the number of yearly reference dates 15 years prior to SD entry) and by wages at SD entry. For instance, if the increase in SD inflow is the result of "better" workers seeking employment protection, we might attribute an improved labor market perfomance (i.e. a smaller gap between pre- and post-labor market success) of an impact of disability policy when in fact the quality of the SD inflow has increased (resulting in a lower pre-/post-SD gap).

Table 4 shows that labor market attachment of beneficiaries prior to SD award did not dramatically change during the 1990s. For females, the percentage beneficiaries that had a continuous employment history slightly fell from 24 percent of 1991-1994 inflow-cohorts to 22 percent of the 1999-2002 cohorts. The situation is similar for males where the fraction of workers with a continuous work history decreased from 44 to 42 percent. Among the other a result, this lead to a sharp increase in disability recepients suffering from mental illnesses and back pain explaining a large part of the increase in disability rolls. 
groups no clear picture emerges. In sum, the quality of the SD inflow - as measured by the labor market attachment prior to SD inflow - did not dramatically change during the observation period.

Table 3,Table 4

Table 5 presents descriptive evidence on wages of (employed) SD entrants. Daily wages of male entrants are 93 percent of the male median wage earner. This suggest that the earnings penalty for severely disabled worker in Austria is quite small. This is in line with evidence provided by OECD (2003) according to which disabled workers in Austria (like those in Switzerland, Italy, Australia, Germany and Poland) earn more than 90 percent of their non-disabled counterparts. $^{8}$ The situation is different for female SDs who earn only 69 percent of the male median wage. The lower female wage could be partly due to a higher prevalence of part-time work (the ASSD does not report hours). Figure 4 show that since that for both males and femals that daily wages of new SD beneficiaries have slightly increased until the mid 1990s but have been decreasing thereafter. Table 5 further reveals that, since the early 1990s, the average wage of a new SD beneficiary has been decreasing somewhat during the 1990 and more strongly after 1999. The only exception are continuously employed males where the relative wage of new SD entrants has remained unchanged throughout the observation period. More importantly, there is no evidence of moral hazard behavior in the sense that workers with better skills are seeking SD status and the associated employment protection. If at all, the average quality of more recent cohorts has decreased. Taken together there is no strong evidence that there was a dramatic change in the quality of SD inflow during the 1990s.

Figure 4, Table 5

\subsection{Employment before and after SD award}

Our next step is to explore how labor market outcomes are affected by SD award and which groups are most strongly affected by getting access to this status. Figure 5 shows how employment-population ratio of the entire sample relates to the time since (or time to) SD entry. The figure reveals that, among individuals who were awarded SD status between 1987 and 2002, 70 percent were employed 5 years prior to the data when they got the legal SD status. The employment rate was even slightly increasing reaching the highest level one year before

\footnotetext{
${ }^{8}$ Note, however, that the OECD evidence is based on survey data from the European Community household panel and based on a self-reported measure of disability that includes both severly disabled and moderately disabled individuals. Notice also that the earnings situation of disabled in these countries is quite different from the U.S. where the disability earnings penalty is about 30 percent.
} 
the SD status was awarded. Thereafter the employment level strongly decreases, reaching a level of about 55 percent 5 years after SD entry.

This picture is is the outcome of two processes. On the one hand, there is the onset of a disability that hampers the employment chances of the individual worker. On the other hand, with the award of legal SD status the disabled individual is subject to EAD rules, mostly importantly extended employment protection, which may have an impact on the employment situation in the future. The fact that the employment rate prior to the SD award is rather stable is prima facie surprising because an SD award should be associated with a preceding negative health shock generating negative employment consequences. However, a serious health problem does not automatically lead to job loss. Workers go on sickness benefits and can at least temporarily keep their jobs. Figure 5 shows that adverse consequences occur over the longer term.

\section{Figure 5}

Figure 5 also shows that the rules of the Austrian EAD to promote employment of disabled individuals do not lead to a major improvement of employment chances of the average $\mathrm{SD}$ worker at later stages. Over the long term the employment population ratio of strongly decreases with time since SD award. This suggests that EAD are ineffective (and may even harm workers, as suggested in U.S. studies on the employment effects of the ADA). Notice, however, that the population captured in Figure 5 is quite heterogenous. It comprises of all age groups, of male and female workers, workers who entered SD status at different time periods, and workers that differ quite strongly by attachment to the labor force.

To learn more about potential heterogeneity in the effects of SD status on employment, we consider the employment rates by time since (time to) SD award for different subgroups (Figure 6). Panel A of Figure 6 shows that there is a very strong difference in the evolution of employment before and after SD award by age. While the employment chance of SD workers that entered this status before age 45 also suffer from decreasing employment rates after SDstatus was awarded, this reduction is relative small. In contrast, for SD workers who entered this status at age 45 or later is quite different. While this group is much more likely to be employed before SD award, the employment chances for this group decrease rapidly with the date when the individual gets SD-status. The reduction in employment rates is dramatic and reaches levels below 40 percent 5 years after SD award.

\section{Figure 6}

Panel B of Figure 6 show differences by sex. Unsurprisingly males have a higher labor market attachment than females before entering SD status and both groups suffer from decreasing 
employment opportunities after that date. More surprisingly, the difference in the employment population ratio between males and females - which is initially almost 15 percentage points strongly shrinks to about 5 percent after SD award. This suggests that negative effects of a severe disability may be less detrimental for females than for males. Alternatively, it could be that EAD rules for severely disabled individuals may be more helpful for women than for men.

Another intersting issue is whether the increased policy efforts during the 1990s may have helped severely disabled individuals keeping their (or finding new) jobs after the onset of their disability. To get a first hint on such effects Panel $\mathrm{C}$ of Figure 6 compares individuals that entered SD status before 1995 to individuals that entered this status in 1995 or later. Clearly the latter group enjoys stronger public support than the former and hence should have a more favorable employment performance after entering SD status. Panel C of Figure 6 shows that the opposite is the case. While there is not much difference between SD cohorts in employment performance before entering SD status, more recent SD cohorts loose much more in terms of employment after entering SD status than earlier cohorts. There are several possible explanations for this results. First, it could be that the economic environment has become harsher for disadvantaged workers in recent times. In many countries the labor market position of less skilled workers has worsened in recent years, and technical progress and/or increased comeptition due to the globalization have been the main explanations. Second, it may be that recent government efforts have attracted new groups to seek SD status that would otherwise not have applied for this status. This could either be a direct effect of these policies: or it could be due to an increased awareness of society of the problems of disabled indivduals in more recent years - which may have encouraged new groups to apply for SD status.

A further dimension that may have important implications for SD effects is labor market attachment. ${ }^{9}$ Individuals with strong attachment to the labor market prior to disability are more likely "classical" beneficiaries hit by a negative health shock and suffering from their disability thereafter. Individuals with a weak attachment to the labor market are more likely groups that are disadvantaged already before they enter SD status. To the extent that this is true, comparing high- and low-attachment tells us more about the relative importance of negative health effects and the direct effects of SD status on subsequent labor market performance. The low attachment group shows a strongly improving employment performance over time which even jumps up at the date when the individual becomes an SD beneficiary and continues to increase thereafter. Of all groups displayed in Firgure 6 this is the only one that experiences increasing employment rates after entering SD status. In contrast, previously strongly attached individuals experience a fall in employment rates that starts one year prior

\footnotetext{
9 "Strong" attachment is defined as being observed in employment at 7 or more of the last 14 reference dates prior to SD entry: "Weak" attachment means employment at less than 7 prior reference dates.
} 
to SD entry and continues to fall thereafter. Interestingly, 5 years after getting SD status employment rates have become almost identical.

\section{Figure 5}

\subsection{Labor earnings before and after SD award}

How do labor earnings of individuals holding SD status vary with time since (and time to) SD award? Figure 7 shows the daily wage of employed SD workers relative to the median daily wage of employed of male private sector workers at the same reference date. 5 years before the average SD worker gets SD-status, relative earnings of SD workers amount to 95 percent of the median earnings of male private sector workers and stays at that level until two years before SD entry. Thereafter the relative wage falls reaching only 85 percent. In post SD-award years, the relative wage recovers again reaching almost pre-SD levels.

\section{Figure 7, Figure 8}

Does this mean that individual acquiring SD status do not suffer from a decrease in labor earnings as a results of their disability? Unfortunately, the answer is no. First, we have to keep in mind that Figure 7 is based on employed workers only and Figures 5 and 6 have shown that times after SD award are associated with strongly detrimental employments for most groups. Figure 9 shows average labor earnings unconditional on employment. This figure shows that mean earnings of all (employed, unemployed, and inactive) SD individuals display strong losses after entering SD status. Second, the graph in Figure 6 does also not necessarily mean that those individuals who manage to keep their job after entering SD status experience a recovery in their earnings. The increase in mean earnings after entering SD observed in Figure 7 could be a selection effect. When only high-wage individuals manage to keep their jobs, average earnings of employed workers increase simply because only high-wage SD workers are employed at later dates. (In the next section we discuss the results from our regression analyses, we will come back to this issue.)

Figure 9, Figure 10

Panels A to D of Figure 8 present pre- and post-SD earnings for different groups. In all groups a similar pattern emerges. Earnings are relatively high early on, gradually reduce as the date of SD award approaches, reach their trough at the date when the individual enters SD status and gradually recovers thereafter. Unsurprisingly, we find that older workers are paid better than younger workers (Panel A) and that males earn more than females (Panel B). Panel $\mathrm{C}$ shows that there is not much difference in terms of earnings between more recent and 
earlier inflow cohorts, both before and after SD award. The fact that both pre-SD earnings and pre-SD employment (see Panel C, Figure 6) of inflow cohorts before and after 1995 reinforces our argument that cohort quality has stayed roughly constant during the 1990s. Worse employment effects of more recent cohorts are most likely the result of forces that work against disadvantaged groups.

Panels A to D of Figure 10 show unconditional earnings of (employed, unemployed and inactive) SD individuals before and after SD award hence the various panels of this figure comprise both wage-effects of the employed and employment effects (of the whole population). Panel A of Figure 10 reveals that overall mean earnings for the young (younger than age 45) mean earnings are higher after SD award than before SD award. In Panel D we see a similar (and even more pronounced) picture for the groups with a weak labor market attachment. For both groups employment effects during the years after SD award are either (the young, Panel A, Figure 6) or even positive (the weakly attached, Panel D, Figure 6) and earnings of the employed recover strongly after SD award (Panels A and D, Figure 8). For all other groups, overall earnings are strongly reduced after SD award. Strong detrimental employment effects are not compensated by increases in earning of workers who remain employed during the years when they hold SD-status.

\section{$6 \quad$ Regression analysis}

Figures 6 - 10 do not (jointly) control for observable differences between groups, in particular age, sex, calendar year, etc.. The analysis above was descriptive and did not try to separate SD effects on the employment and earnings careers of disabled workers. In this section we undertake a regression analysis that controls for observable heterogeneity and provides summary estimates for the effects of SD status on workers subsequent employment and earnings carrer.

We proceed by first presented our regression model and then show the results. In particular, we will focus on the issue whether SD effects differ by age and sex, as suggested in Figures 6 and 8 , and whether SD effects differ by employment status at the date of entry into SD status. Finally, we look at the question whether SD effects have changed over time trying to answer the question whether policies of the Austrian government towards disabled individuals have become more or less effective during that period. 


\subsection{The econometric model}

To control for observed differences and to obtain summary estimates for the differences before and after SD award we perform regression analyses. We run the following regression

$$
Y(i, t)=a_{0}+a_{1} D(i, t)+\sum_{j} b_{j} X_{j}(i, t)+\sum_{k} c_{k} x_{k}(i)+e(i, t)
$$

where $Y(i, t)$ is the labor market outcome of individual $i$ at date $t, D(i, t)$ is a dummy variable that indicates whether individual $i$ hold SD-status at date $t, X_{j}(i, t)$ (and $x_{k}(i)$ ) are time-varying (and time-invariant) co-variates, and $e(i, t)$ is an error term satisfying the usual assumption which captures unobservable (to the researcher) factors influencing labor market outcomes. $a_{0}, a_{1}$, the $b_{j}$ 's, and the $c_{k}$ 's are coefficients to be estimated. The coefficient of particular interest is $a_{1}$ which provides us with a summary statistic about the impact of SD-status on labor market outcomes of individual $i$.

A crucial issue is whether the error term $e(i, t)$ is correlated with the disablity-status dummy $D(i, t)$. Let us assume that individuals differ by unobservable but time-invariant characteristics such that that $e(i, t)=\varepsilon(i, t)+\eta(i)$ where $\varepsilon(i, t)$ is an i.i.d. error term and $\eta(i)$ is the individual fixed effect. Consider first employment status as the relevant labor market outcome. Will $e(i, t)$ and $D(i, t)$ be correlated? The answer is no, if the sample is perfectly balanced and all individuals are observed at all 5 dates before and after SD entry. Note, however, that our sample is not perfectly balanced. While we observe all cohorts entering 1997 or earlier at all 5 dates before and after SD entry, cohort entering 1998 or later are observed indeed 5 times before SD entry but less than 5 times after SD entry (recall that our data end in 2002). This causes a correlation between if more recent cohorts are of different quality than less recent cohorts (in that case $\eta(i)$ for more recent cohorts differs systematically from less recent cohorts).

Now consider the daily wage as the relevant labor market outcome. Here $e(i, t)$ and $D(i, t)$ may be correlated because the relative-wage sample is not balanced by construction. Individuals are only observed if they hold a job. If high-wage individuals (those with a high $\eta(i)$ ) are more frequently employed, we get a positive correlation between $e(i, t)$ and $D(i, t)$. In that case case OLS results will be biased.

In order to account for potential problems arising from time-invariant unobservables, the regression below will allow for individual fixed effects. The fixed effects regression takes the form

$$
Y(i, t)=\alpha_{0}+\alpha_{1} D(i, t)+\sum_{j} \beta_{j} X_{j}(i, t)+\eta(i)+\varepsilon(i, t)
$$

where all (observable) time-invariant variables (the $x_{k}$ 's) are now captured by the fixed effect $\eta(i)$. 


\subsection{Results}

The results are presented in three steps. We first look at our baseline model. In this model we only consider age, sex, and calendar time as control variables. We run the baseline model using the whole sample and check to which extent effects vary by age. We then look at the impact of policies, in particular whether differential effects arise between employed and non-employed individuals as a results of the employment protection rules of the Austrian EAD. Finally, we look for changes in SD-effects over time. Those allow us to test whether policies have played an active role in bringing SD-individuals back to work (and enhance their earnings), or whether policies have played a more passive role reacting endogenously to a harsher economic environment for the disabled.

Baseline model Table 6 presents results from OLS- and fixed effects models for both employment and relative earnings. The analysis is based on the whole sample and all specifications include age, sex, calendar-time dummies as explanatory variables, but the table only reports the coefficient of the $D(i, t)$ variable that indicates whether the individual holds SD-status at the particular date. (Appendix A2 presents results for all coefficients).

\section{Table 6}

Results indicate that holding an SD status is associated with signficantly worse labor market outcomes. The OLS employment regression suggests that the employment rate after entering SD status is almost 7 percentage points lower than before entering that status. Both sign and size of the effect are perfectly in line with what we have seen in Figure 6 above. However, the fixed effects (FE) regression implies that the loss in employment is much smaller and amounts to only 1.3 percentage points. If a bias of OLS results arises from neglecting individual (timeinvariant) effects, this suggests that more recent cohorts are systematically different from earlier cohorts in the stability of their employment. (In fact, given age, sex, and calendar-time, the FE-result suggests that less recent cohorts have less stable employment).

The OLS relative wage estimates suggests that wages are lower after SD entry. (Notice that this coefficient captures the average effect of SD-status on relative wages at dates $0,1, \ldots, 5$ after SD entry. Figures 8 and 9 suggest that there is variation in these effects across periods). We find very similar effects of SD-status in the FE-model and the OLS. According to the latter, relative earnings decrease by 1.6 percentage points whereas the FE-models estimates a reduction in relative earnings by 3.0 percentage points. This suggests that those who manage to remain in employment suffer earnings losses that relatively small.

Table 7 looks at differences in the SD employment-effect by age and sex. All coefficients reported in the table are obtained from the FE-model that is identical to the one of Table 6 . It 
turns out that SD status helps to bring young workers back to work, the effect being stronger for women than for men. In contrast, the employment situation of older workers significantly deteriorates after entering SD-status.

Table 7

In Table 8 we perform a similar analysis using relative earnings as the dependent variable. We find that earnings significantly decrease in all groups with the young suffering a smaller earnings penalty than older wokers. In sum, Tables 7 and 8 suggest heterogeneity in SDeffects are important with age effects being the dominant one. Hence the following analysis concentrates on differences in SD-effects across age groups but does no longer distinguish between males and females.

Table 8

Does employment status at SD entry make a difference? A major incentive for a disabled individual to apply for SD status is extended employment protection for SD beneficiaries. Note, however, that the effects of these EAD rules may be quite different for employed individuals as opposed to individuals who do not hold a job. While increasing the firing costs for employers should have a positive impact on subsequent job stability of individuals who currently hold a job, such costs may make firms reluctant to hire workers eligible for extended employment protection.

To test this hypothesis we split our sample into those individuals who are at work the date of SD inflow and the remaining individuals that are either unemployed or inactive at that date. Table 9 presents our results. They clearly show that disabled individuals strongly benefit from holding SD-status when they are employed at the date of SD entry. Notice also that the quantitative size of the effect is very important, employment probabilities increase by 10 percentage points for the whole sample and by 14 percentage points for workers younger than 45. Even older workers benefit from SD-status when employed. The situation is quite different when workers are unemployed at SD entry. This group suffers dramatically when getting the SD status. Employment chances are reduced by 29.4 percentage points when entering SD-status, the situation being particularly dramatic for individuals 45 years or older. For them the employment rate decreases by 35 percentage points.

Table 9

It is also interesting to look at the evolution of wage between employed and non-employed workers with respect to SD-status. Panel A of Table 10 shows that employed workers - while 
having much more stable employment suffer from earnings losses of 4.4 percent and are stronger among older workers. Panel B of Table 10 shows that those few non-employed workers who manage to get a new job after entering SD-status do significantly better in terms of wages than before. A possible explanation for this result is that there is a small group of individuals for whom the disablilty shock turns out as new chance on the labor market.

Do SD effects change during the 1990s? Finally we look at the question whether increased policy efforts of the Austrian government during the 1990s had any major impact on labor market outcomes of SD workers. To assess this issue we interact the variable $D(i, t)$ that indicates a worker's SD status with calendar-time dummies for the years 1991-1994, 1995-1998, and 1999-2002. Table 10 present the FE-results for employment status. The first column reports the overall effects. As it becomes obvious from the coefficients, the effects have become more negative over the 1990 indicating much worse employment performance in recent years as opposed to the early 1990s. Column 2 and 3 split the sample by age at SD-inflow into younger workers (below age 45, column 2) and older workers (45 or older, column 3). Interestingly, it turns out that employment losses were exclusively concentrated among older workers whereas the SD-employment effects of younger workers stayed constant over the observations period disabled workers.

Table 10 and Table 11

Table 11 performs a similar analysis for the relative wages of employed workers. Here we see a slight improvement by the end of the 1990s for the observation period, both for younger and for older workers. In sum, our results suggest that increased policy effort had positive impacts for employed workers and have possibly also helped to keep employment prospects of younger workers from deteriorating. However, the employment prospects for older SD individuals has dramatically worsened.

\section{Conclusions}

In this paper we have studied the employment and wage impacts of the policies to promote severely disabled (SD) workers in Austria. These policies grant extended employment protection for SD workers, oblige firms to hire a minimum number of SD workers, and subsidize the employment of these workers. This program has been strongly expanded since the early 1990s increasing from 1.2 percent of the employed (15-64) population in 1990 to 2.4 percent in 2005.

We have used a very large data set providing detailed longitudingal information on the work and earnings history of disabled individuals. Unlike many other studies which rely on 
self-reported disability our measure of severe disability is an objective assessment of the health status of a worker resulting from the application process to acquire the legal SD-status.

Our descriptive analysis indicates that, unsurprisingly, holding SD-status is associated with lower employment and lower wages, most likely reflecting lower productivity with the onset of a severe disability. We also find that employment prospects become worse the longer the individual holds SD-status and the reduced employment prospects are dramatic among older $(45+)$ workers but small for younger workers.

Our results from regression analysis (which account for individual fixed effects) indicate that employment effects are smaller than the descriptive analysis indicates. However, significant detrimental earnings effects remain. A major incentive for a disabled individual to apply for SD status is extended employment protection for SD beneficiaries which imposes substantial firing costs on firms when laying off SD-workers. We find that individuals who hold a job at SD-entry enjoy strong employment gains whereas for individuals who do not have a job at SDentry employment prospects are dramatically reduced. This is in line with the hypothesis that employment protection legislation with respect to disabled individuals have a strong impact on hiring decisions of firms. 


\section{References}

Acemoglu, Daron und Joshua D. Angrist (2001). Consequences of Employment Protection? The Case of the American with Disabilities Act. Journal of Political Economy, 109(5), 915-957.

Autor, David H. and Mark G. Duggan (2006), The Growth in the Social Security Disability Rolls: A Fiscal Crisis Unfolding, Journal of Economic Perspectives 20: 71-96.

Badelt, Christoph und August Österle (1993). Zur Lebenssituation behinderter Menschen in Österreich, Bundesministerium für Arbeit und Soziales, Wien.

Baldwin M. and Johnson W.G. (2000) Labor Market Discrimination Against Men with Disabilities in the Year of the ADA, Southern Economic Journal 66: 548-566.

Beegle, K. and Stock, W. A. (2003). The Labor Market Effects of Disability Discrimination Laws. Journal of Human Resources 38: 806-859.

Bell, David und Axel Heitmüller (2005). The Disability Discrimination Act in the UK: Helping or Hindering Employment Amongst the Disabled? IZA discussion paper no. 1476.

Bound, John und Richard V. Burkhauser (1999). Economic Analysis of Transfer Programs Targeted on People with Disabilities. In: Orley Ashenfelter und David Card (eds.), Handbook of Labor Economics, Vol. 3C.

BMSG (2003). Bericht über die Lage der behinderten Menschen in Österreich, Bundesministerium für Soziale Sicherheit und Generationen, Wien.

Burkhauser, Richard V. J.S. Butler und Yang Woo Kim (1995). The Importance of Employer Accomodation on the Job Duration of Workers with Disabilities: A Hazard Model Approach. Labour Economics, 3(1), 1-22.

Burkhauser, R. and Daly, M. (1998), Disability and Work: the experiences of American and German men, Federal Reserve Bank of San Francisco Economic Review 2: 17-29.

Burkhauser, Richard V., Mary C. Daly and Andrew J. Houtenville (2001) "How Working Age People with Disabilities Fared Over the 1990s Business Cycle." In Peter Budetti, Richard V. Burkhauser, Janice Gregory and Allan Hunt (eds.), Ensuring Health and Income Security for an Aging Workforce. Kalamazoo, MI: W.E. UpJohn Institute for Employment Research, pp. 291-346.

Daly, Mary C. (1997) Who is Protected by the ADA? Evidence from the German Experience. Annals of the American Academy 549: 101-116.

DeLeire Thomas (2000). The Unintended Consequences of the Americans with Disabilities Act. Regulation, 23(1), 21-24.

Dyk, I. et al (2002), Arbeitsmarktchancen für Menschen mit Behinderungen, Eine empirische Untersuchung in oberösterreichischen Unternehmen über die Arbeitsmarktchancen von Menschen mit Behinderungen, Studie im Auftrag der OÖ Landesregierung und in Kooperation mit der O.Ö. Wirtschaftskammer, Linz 2002. 
Dyk, I. et al. (2004), Von der Schule in den Beruf, Empirische Studie über den Werdegang integrativ betreuter Schüler und Schülerinnen nach Beendigung der Pflichtschuzeit in O.Ö, $2003 / 2004$.

European Commission (2001), The employment situation of people with disabilities in the European Union, Directorate-General for Employent and Social Affairs.

Jolls, Christine and J.J. Prescott (2004), "Disaggregating Employment Protection: The Case of Disability Discrimination," NBER Working Paper No.10740, Cambridge MA.

Jolls, Christine (2004), Identifying the Effects of the Americans with Disabilities Act Using State-Law Variation: Preliminary Evidence on Educational Participation Effects, American Economic Review 94: 447-453.

Kidd M.P., Sloane P.J. and Ferko I. (2000) 'Disability and the labour market: an analysis of British males', Journal of Health Economics, 19, 961-81.

Kruse, D. and Schur, L. (2003). Employment of People with Disabilities Following the ADA. Industrial Relations 42: 31-66.

Lalive Rafael, Jean-Philippe Wuellrich, and Josef Zweimüller (2007), Do Financial Incentives for Firms Promote Employment of Disabled Workers? A Regression Discontinuity Approach, mimeo, Universities of Lausanne and Zurich.

Lechner, Michael and Rosalia Vazquez-Alvarez (2003) The Effect of Disability on Labour Market Outcomes in Germany: Evidence from Matching, IZA Discussion Paper No.967.

OECD (2003), Transforming Disability into Ability, Paris.

OECD (1992), Employment Policies for People with Disabilities: Report by Evaluation Panel, Labor Market and Social Policy Occasional Papers No.8, Paris.

Wagner, Joachim, Claus Schnabel, and Arnd Kölling (2001), Threshold Values in German Labor Law and Job Dynamics in Small Firms: The Case of the Disability Law, IZA Discussion Paper No.386. 


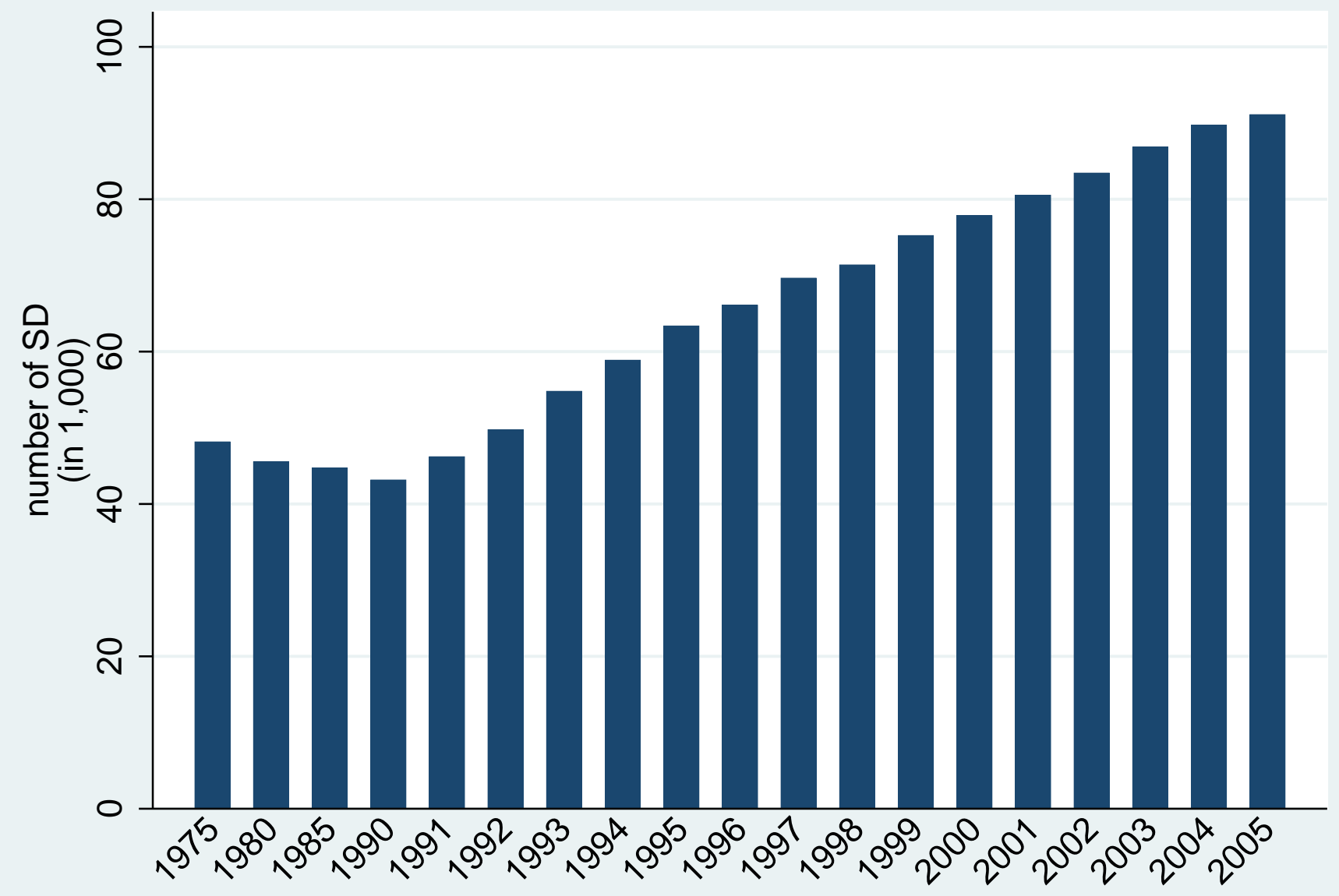

Source: BMSG (2005)

Figure 1: Stock of disabled, 1975-2005 


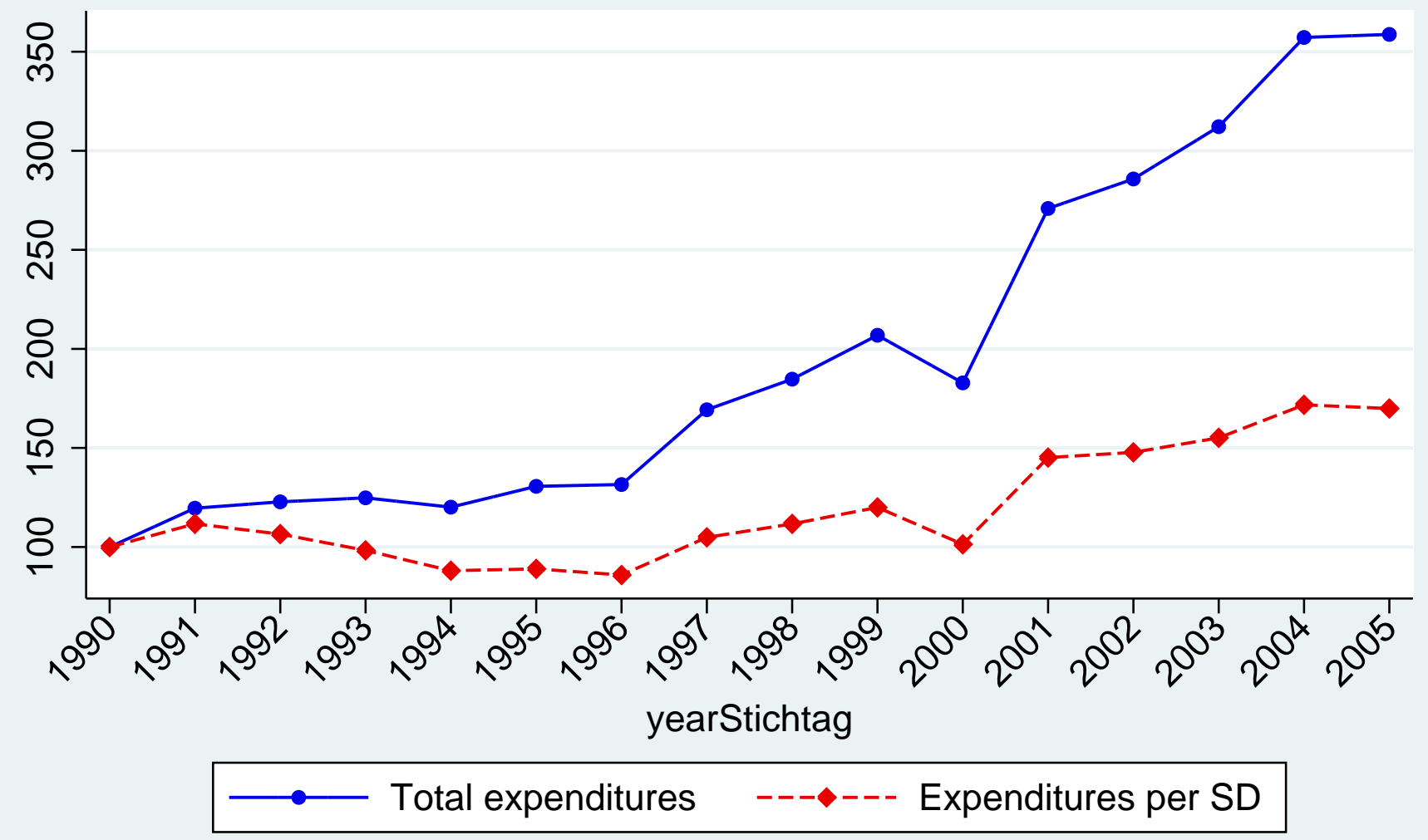

The euro amount in 1990 is set to 100.

Total real expenditures (in 2005 euros); 1990: 44,375,400 euro, 2005: 159,191,800 euro

Real Expenditures (in 2005 euros); 1990: 1,028 euro, 2005: 1,747 euro

Source: Own calculations based on BMSG

Figure 2: Real government expenditures, 1990-2005 


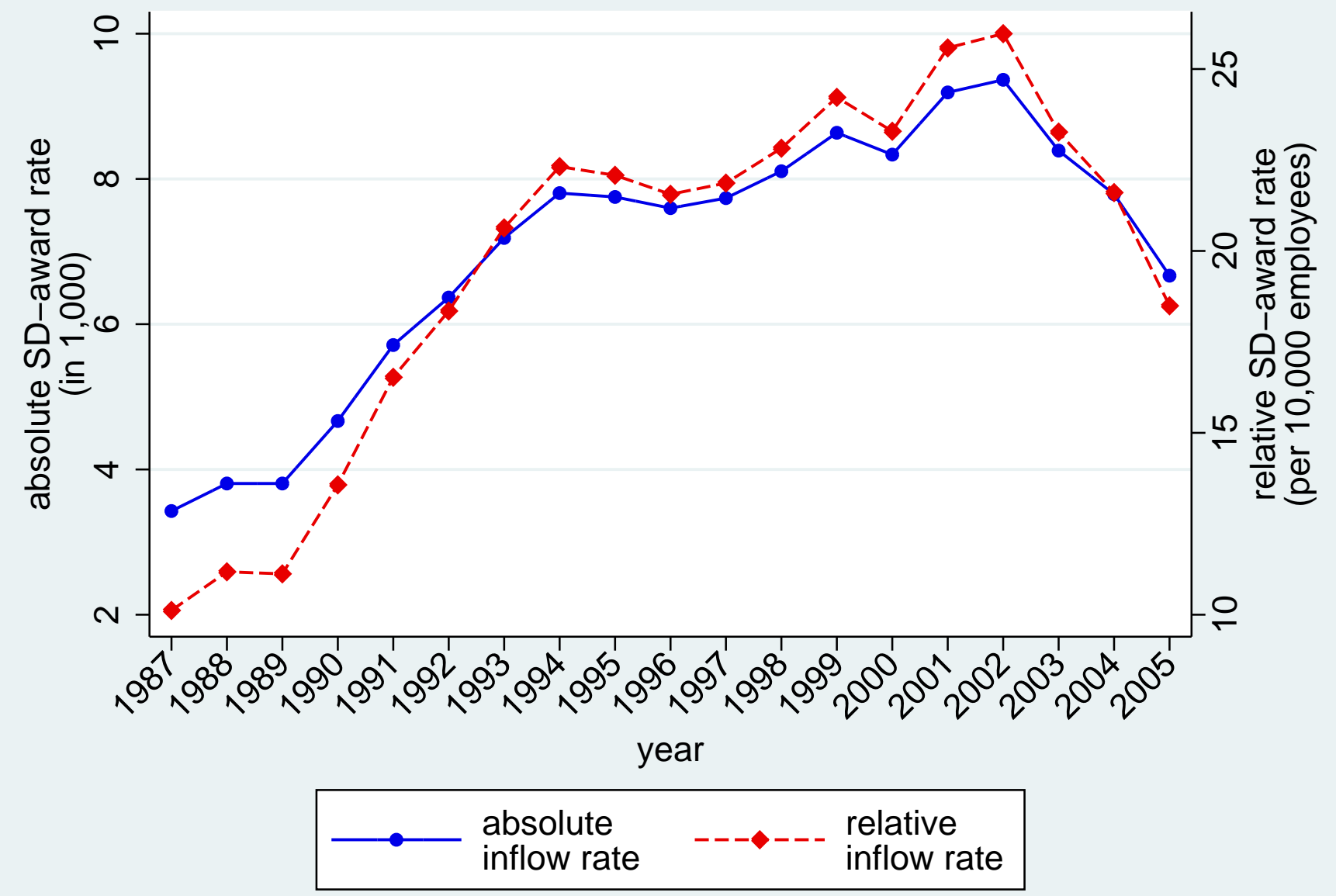

Source: Own calculations based on BMSG and Austrian Census (1981, 1991, 2001)

Figure 3: Inflow into SD status ("SD-award rates"), 1987-2005 


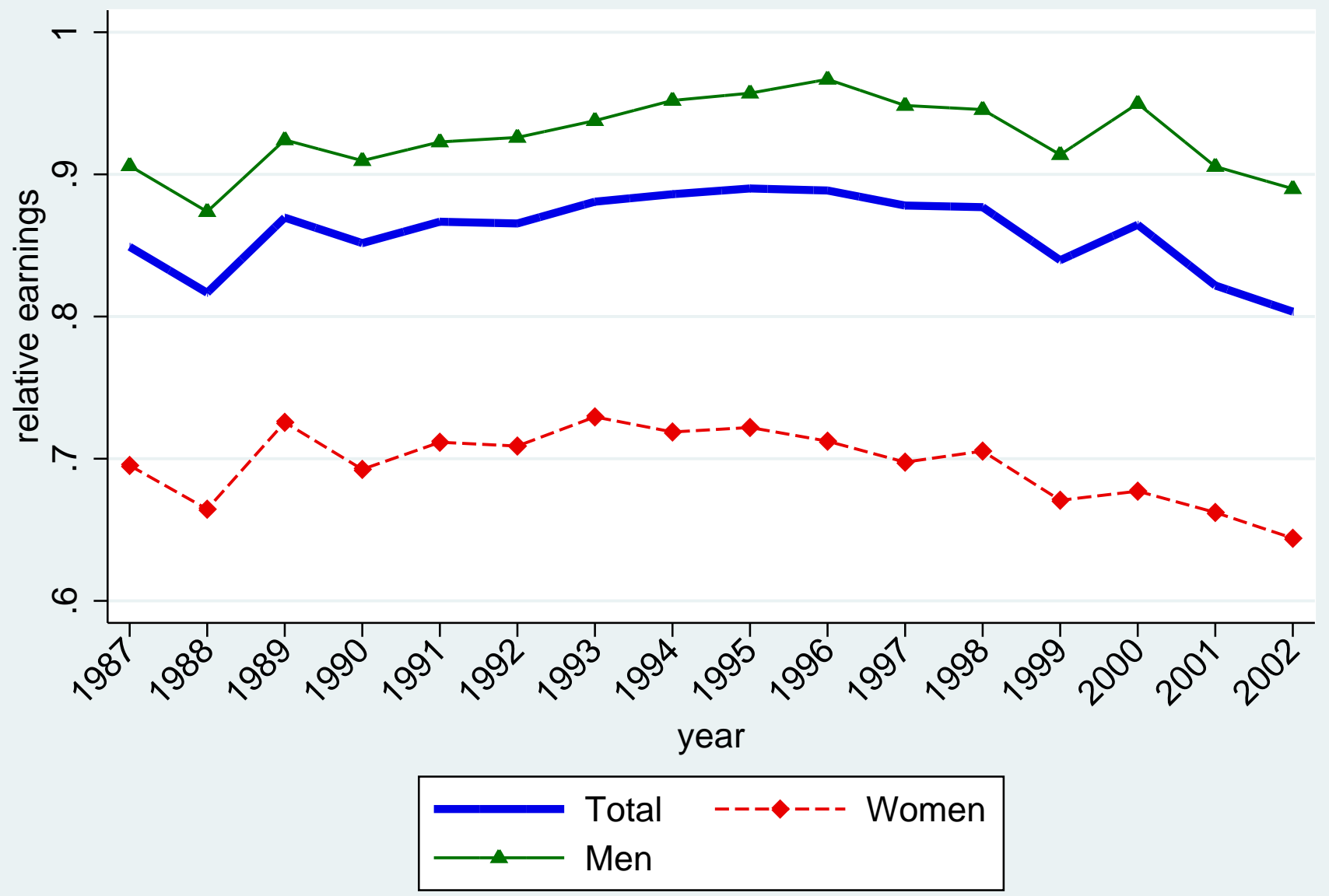

Source: Own calculations based on ASSD and BMSG

Figure 4: Relative earnings at inflow date, employed SD beneficiaries only, by inflow date 


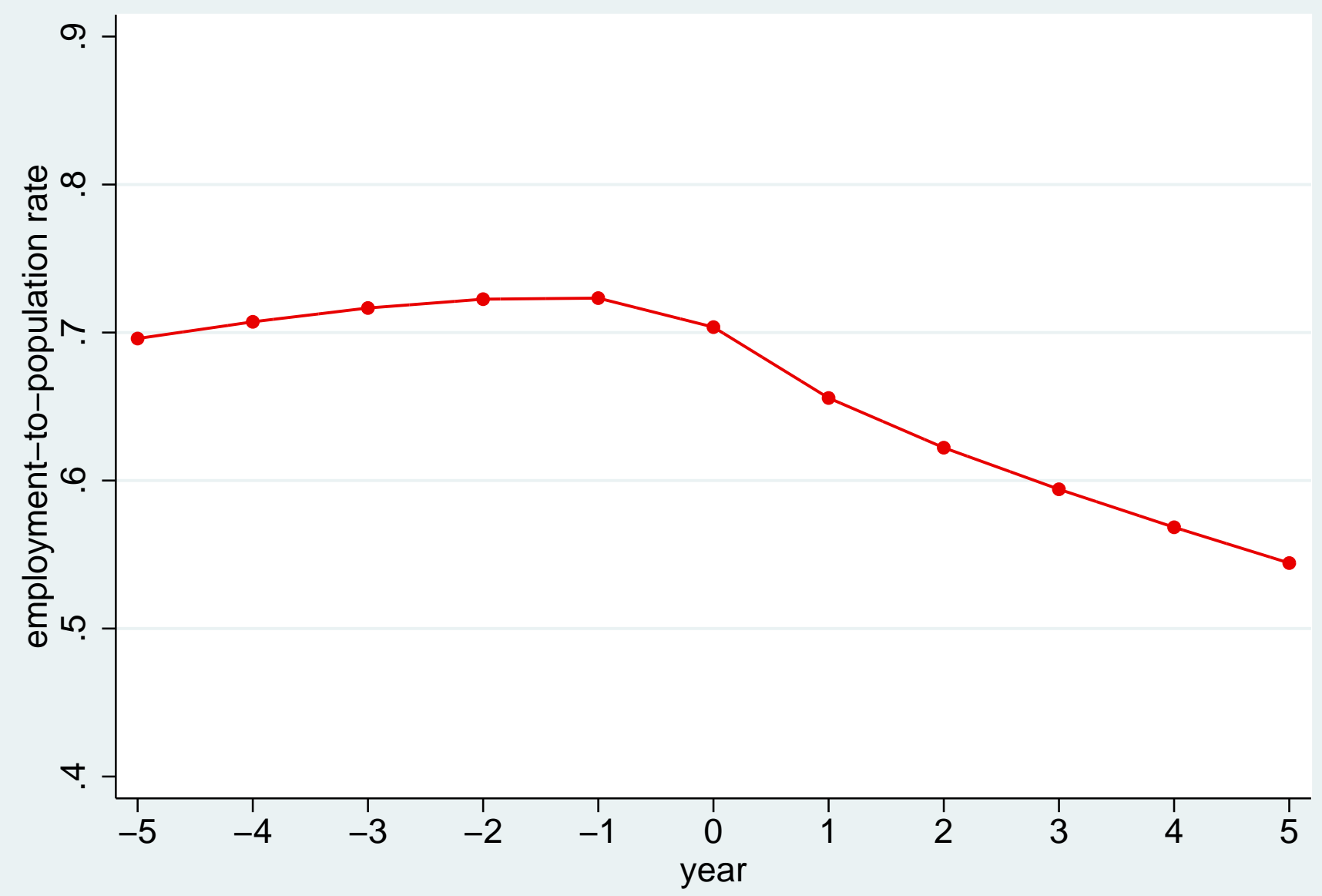

Source: Own calculations based on ASSD and BMSG

Figure 5: SD employment rates, pre-/post-SD award 

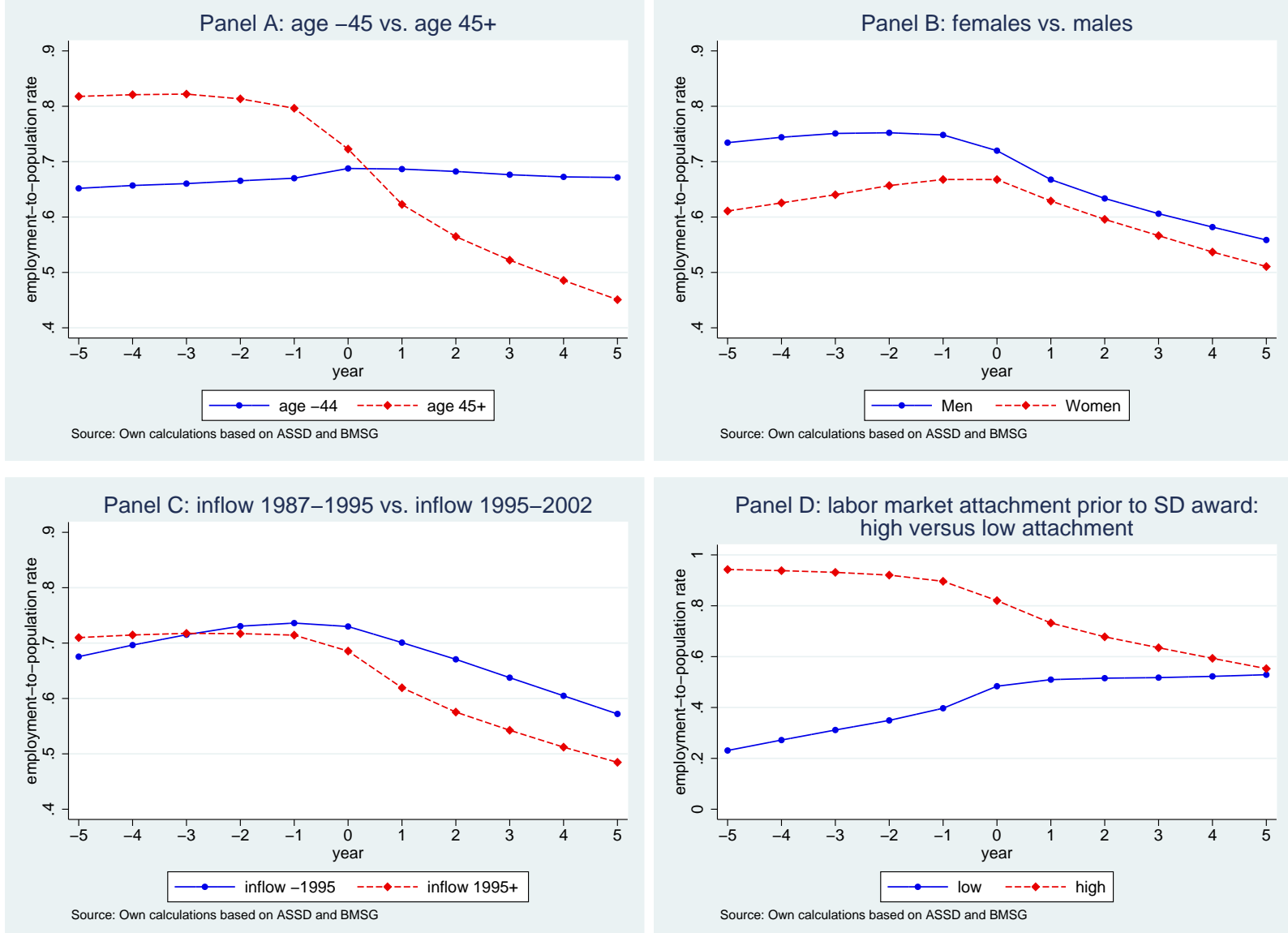

Figure 6: SD employment rate, pre-/post-SD award, by subgroups 


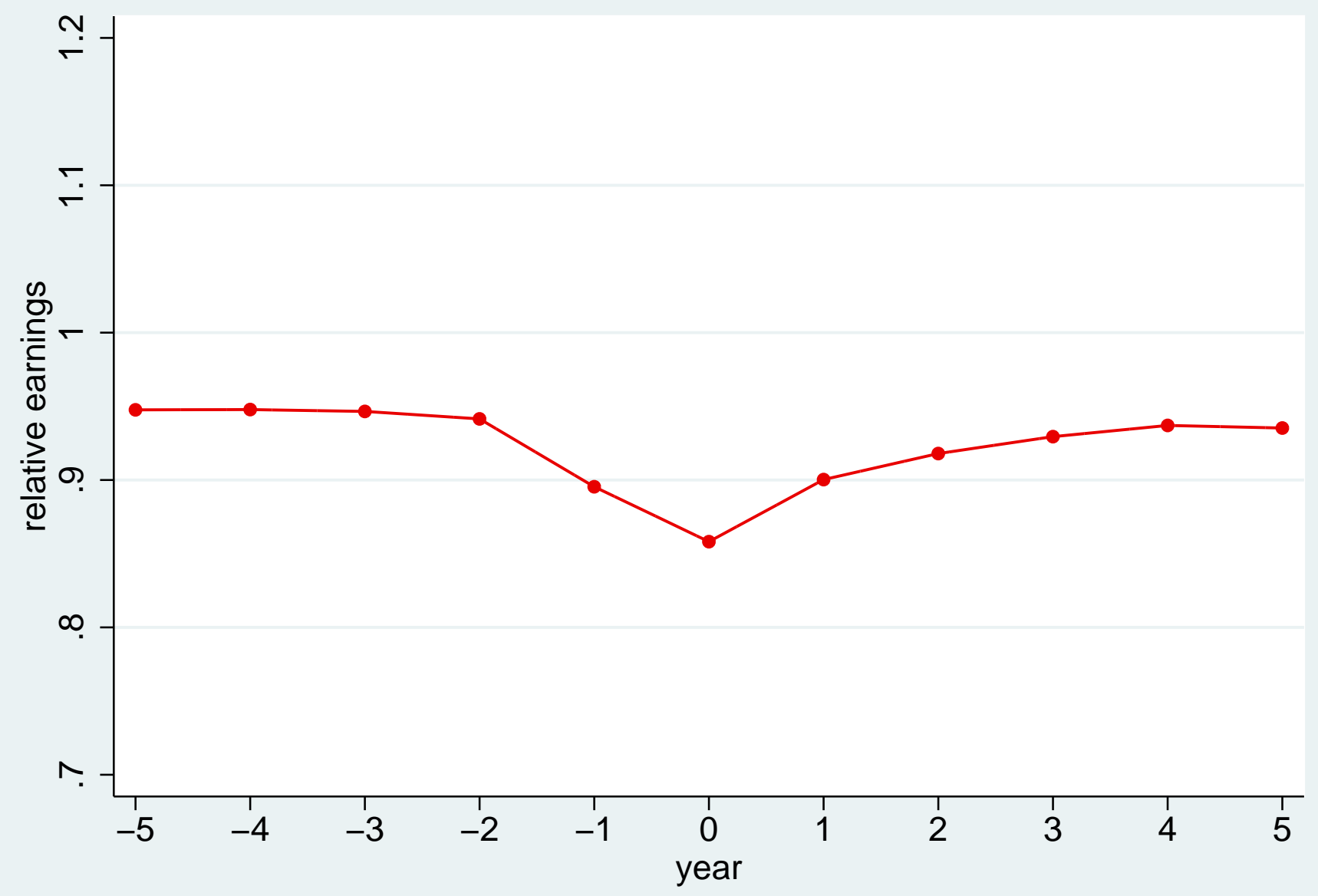

Source: Own calculations based on ASSD and BMSG

Figure 7: Relative earnings of employed SD beneficiaries, pre-/post-SD award 

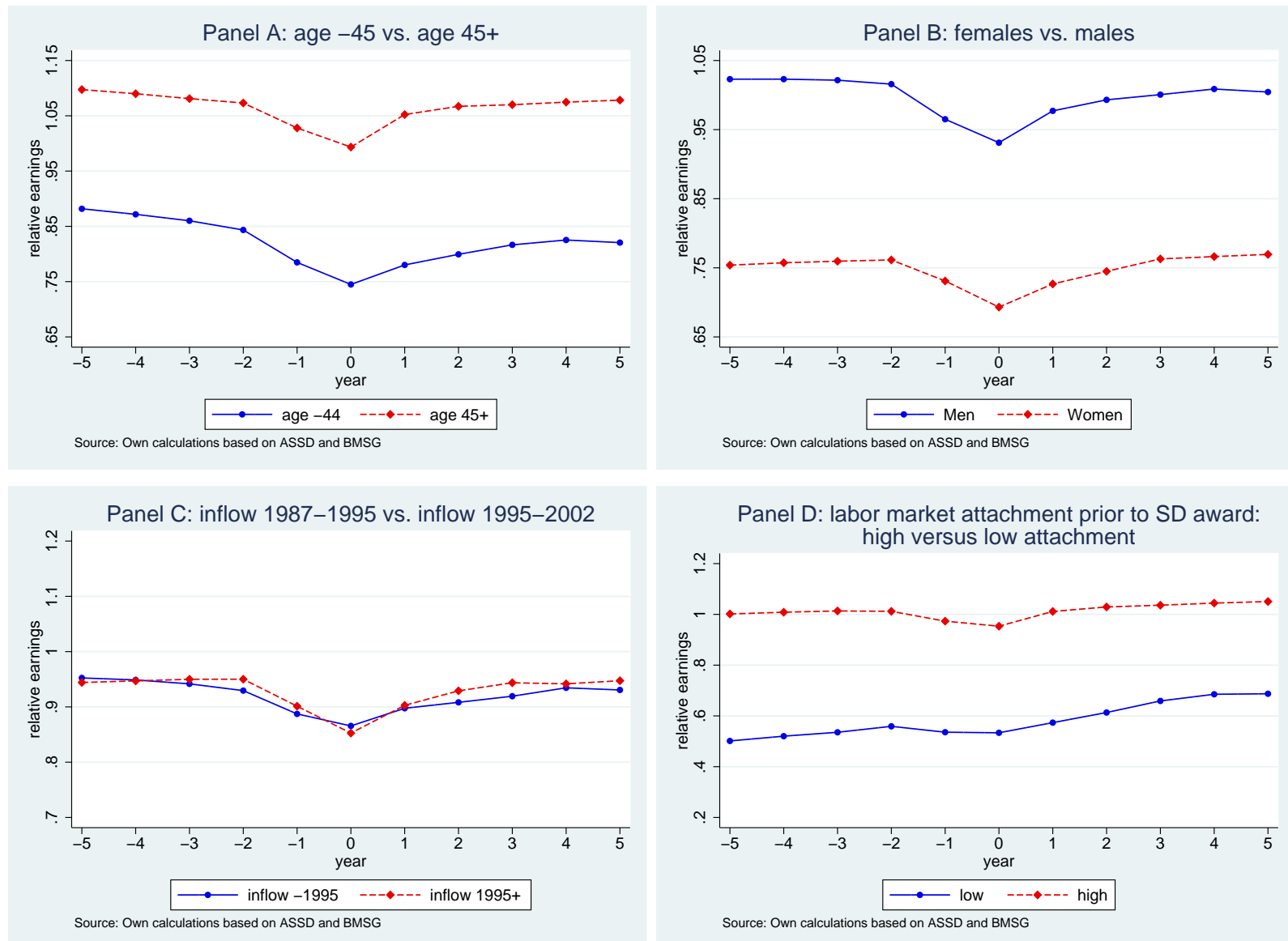

Figure 8: Relative earnings of employed SD beneficiaries, pre-/post-SD award, by subgroups 


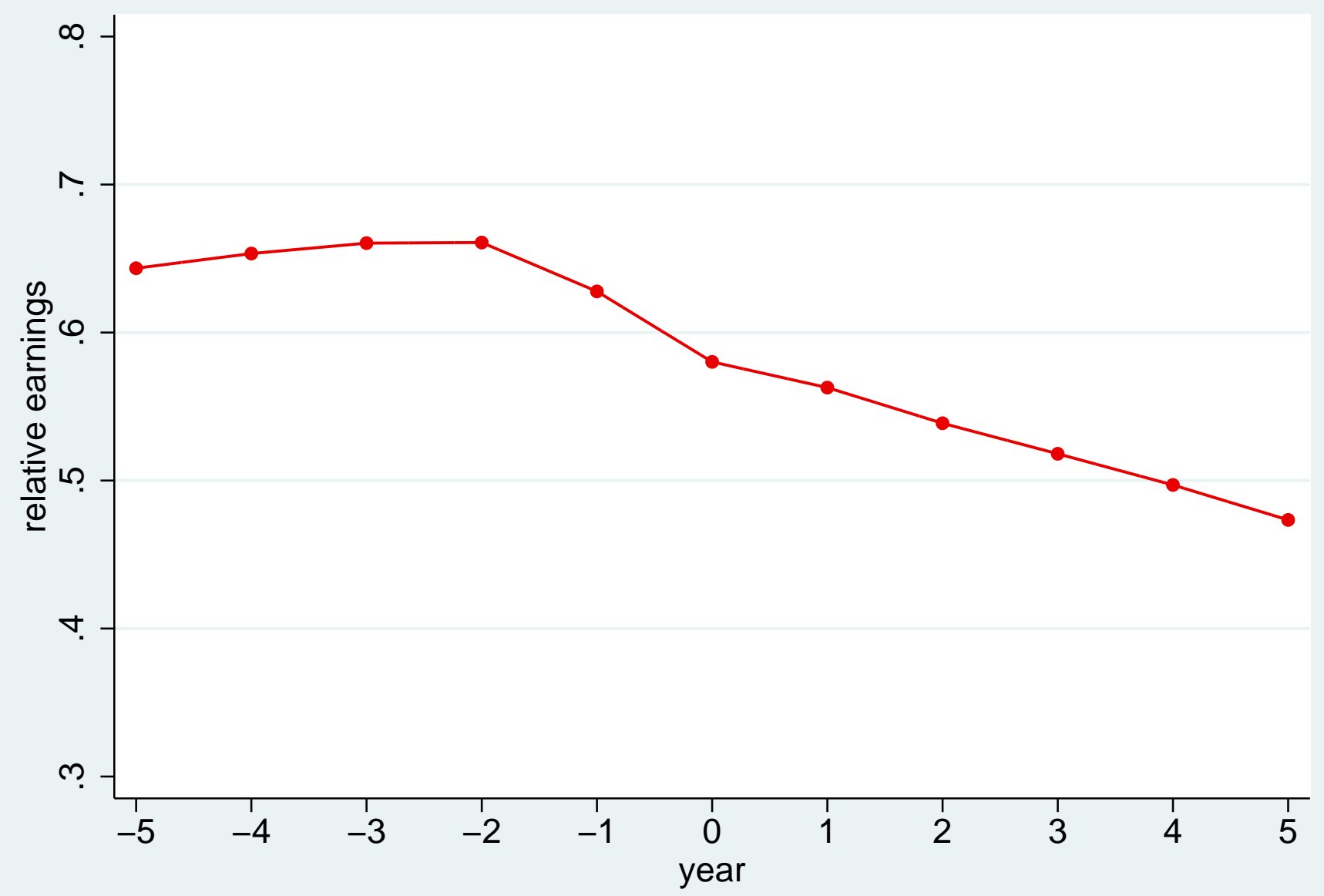

Source: Own calculations based on ASSD and BMSG

Figure 9: Relative earnings of all SD beneficiaries, pre-/post-SD award 

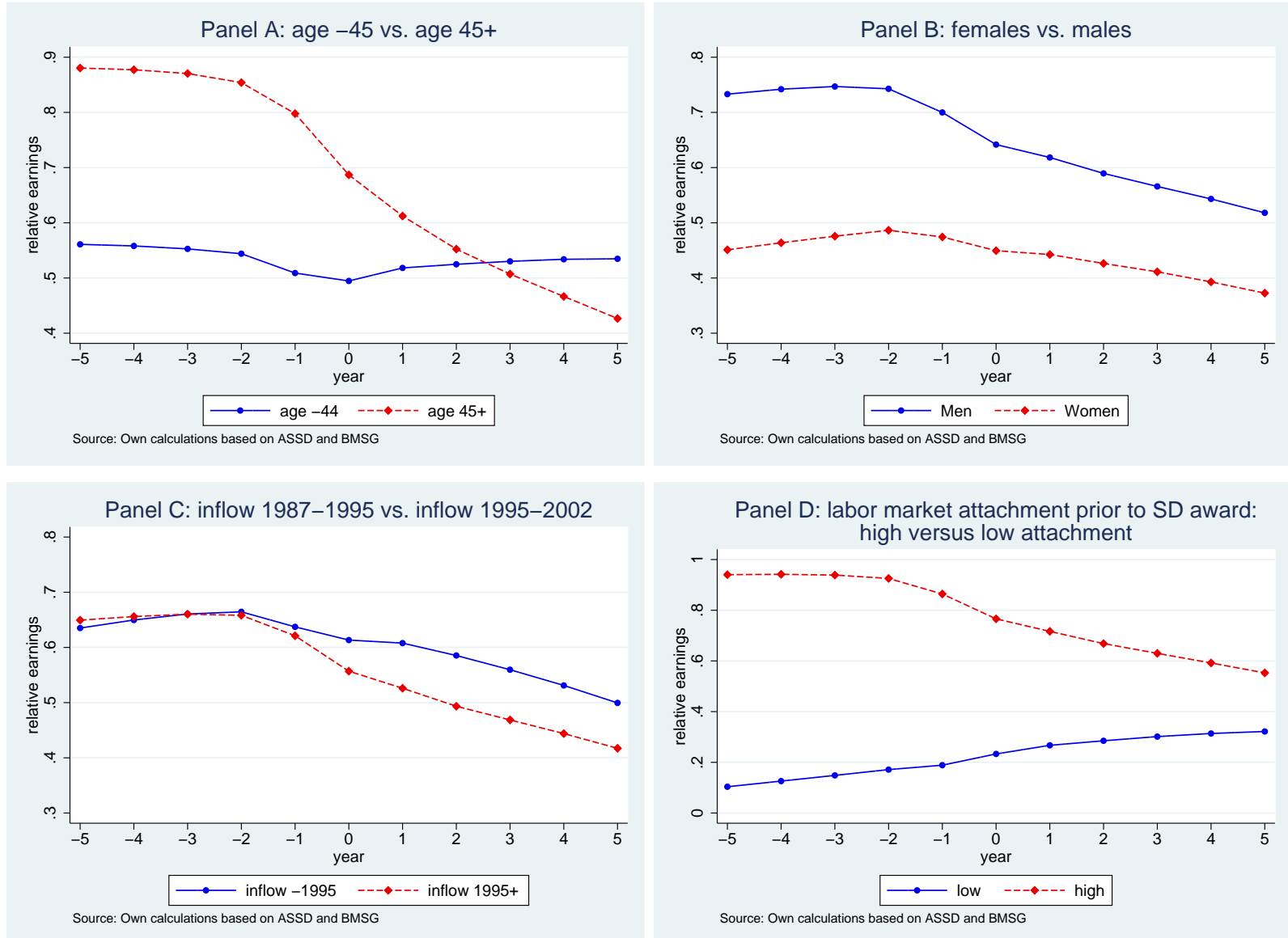

Figure 10: Relative earnings of all SD beneficiaries, pre-/post-SD award, by subgroups 
Table 1: Composition of SD awards, by age and sex, 1987-2005

\begin{tabular}{|c|c|c|c|c|c|}
\hline $\begin{array}{l}\text { Calendar } \\
\text { year }\end{array}$ & $\begin{array}{c}\text { Total } \\
\text { absolute inflow }\end{array}$ & $\begin{array}{l}\text { Percentage } \\
\text { female }\end{array}$ & $\begin{array}{c}\text { Percentage } \\
\text { men }\end{array}$ & $\begin{array}{c}\text { Percentage } \\
\text { age }<45\end{array}$ & $\begin{array}{c}\text { Percentage } \\
\text { age } \geq 45\end{array}$ \\
\hline 1987 & 3,428 & 28.41 & 71.59 & 78.41 & 21.59 \\
\hline 1988 & 3,807 & 29.58 & 70.42 & 73.68 & 26.32 \\
\hline 1989 & 3,807 & 28.71 & 71.29 & 69.61 & 30.39 \\
\hline 1990 & 4,667 & 30.10 & 69.90 & 65.95 & 34.05 \\
\hline 1991 & 5,713 & 29.34 & 70.66 & 61.53 & 38.47 \\
\hline 1992 & 6,367 & 30.14 & 69.86 & 58.11 & 41.89 \\
\hline 1993 & 7,188 & 29.69 & 70.31 & 54.88 & 45.12 \\
\hline 1994 & 7,805 & 30.06 & 69.94 & 52.34 & 47.66 \\
\hline 1995 & 7,752 & 31.04 & 68.96 & 51.20 & 48.80 \\
\hline 1996 & 7,598 & 31.06 & 68.94 & 52.66 & 47.34 \\
\hline 1997 & 7,736 & 29.73 & 70.27 & 51.69 & 48.31 \\
\hline 1998 & 8,106 & 30.40 & 69.60 & 52.95 & 47.05 \\
\hline 1999 & 8,636 & 31.37 & 68.63 & 52.01 & 47.99 \\
\hline 2000 & 8,335 & 32.75 & 67.25 & 49.60 & 50.40 \\
\hline 2001 & 9,191 & 35.55 & 64.45 & 54.27 & 45.73 \\
\hline 2002 & 9,365 & 34.79 & 65.21 & 52.40 & 47.60 \\
\hline 2003 & 8,390 & 33.79 & 66.21 & 46.36 & 53.64 \\
\hline 2004 & 7,790 & 36.05 & 63.95 & 47.47 & 52.53 \\
\hline 2005 & 6,668 & 37.19 & 62.81 & 46.12 & 53.88 \\
\hline Total & 132,349 & 42,290 & 90,059 & 71,911 & 60,438 \\
\hline
\end{tabular}

Source: Own calculations based on ASSD and BMSG. 
Table 2: Composition of SD awards, by degree of work incapacity, 1987-2005

\begin{tabular}{lccccc}
\hline \hline \multirow{2}{*}{$\begin{array}{l}\text { Calendar } \\
\text { year }\end{array}$} & $\begin{array}{c}\text { Total } \\
\text { absolute inflow }\end{array}$ & $\begin{array}{c}\text { Percentage } \\
\text { degree 50 }\end{array}$ & $\begin{array}{c}\text { Percentage } \\
\text { degree 51-60 }\end{array}$ & $\begin{array}{c}\text { Percentage } \\
\text { degree 61-75 }\end{array}$ & $\begin{array}{c}\text { Percentage } \\
\text { degree 76-100 }\end{array}$ \\
\cline { 2 - 6 } $1987-1990$ & 15,709 & 0.46 & 0.22 & 0.14 & 0.17 \\
$1991-1994$ & 27,073 & 0.49 & 0.21 & 0.15 & 0.16 \\
$1995-1998$ & 31,192 & 0.52 & 0.20 & 0.14 & 0.14 \\
$1999-2002$ & 35,527 & 0.58 & 0.18 & 0.12 & 0.12 \\
$2003-2005$ & 22,848 & 0.59 & 0.18 & 0.11 & 0.12 \\
\hline \hline
\end{tabular}

Source: Own calculations based on ASSD and BMSG. 
Table 3: Composition of SD awards, by employment status at SD-inflow date

\begin{tabular}{|c|c|c|c|c|c|c|c|c|}
\hline & \multicolumn{2}{|c|}{$\begin{array}{c}\text { Total } \\
\text { absolute inflow }\end{array}$} & \multicolumn{2}{|c|}{$\begin{array}{l}\text { Percentage } \\
\text { employed }\end{array}$} & \multicolumn{2}{|c|}{$\begin{array}{l}\text { Percentage } \\
\text { unemployed }\end{array}$} & \multicolumn{2}{|c|}{$\begin{array}{l}\text { Percentage } \\
\text { inactive }\end{array}$} \\
\hline & female & male & female & male & female & male & female & male \\
\hline Total Sample & 33,318 & 73,447 & 0.67 & 0.72 & 0.13 & 0.13 & 0.20 & 0.15 \\
\hline \multicolumn{9}{|l|}{ A. Age } \\
\hline Age $<45$ & 21,746 & 38,607 & 0.66 & 0.71 & 0.15 & 0.15 & 0.19 & 0.14 \\
\hline Age $\geq 45$ & 11,572 & 34,840 & 0.69 & 0.74 & 0.10 & 0.10 & 0.21 & 0.16 \\
\hline \multicolumn{9}{|c|}{ B. Inflow cohort } \\
\hline 1987-1990 & 4,396 & 10,704 & 0.68 & 0.75 & 0.13 & 0.11 & 0.19 & 0.14 \\
\hline 1991-1994 & 7,821 & 18,395 & 0.68 & 0.76 & 0.14 & 0.12 & 0.18 & 0.12 \\
\hline 1995-1998 & 9,325 & 21,148 & 0.67 & 0.72 & 0.14 & 0.14 & 0.19 & 0.14 \\
\hline 1999-2002 & 11,776 & 23,200 & 0.67 & 0.69 & 0.12 & 0.12 & 0.21 & 0.19 \\
\hline
\end{tabular}

Source: Own calculations based on ASSD and BMSG. 


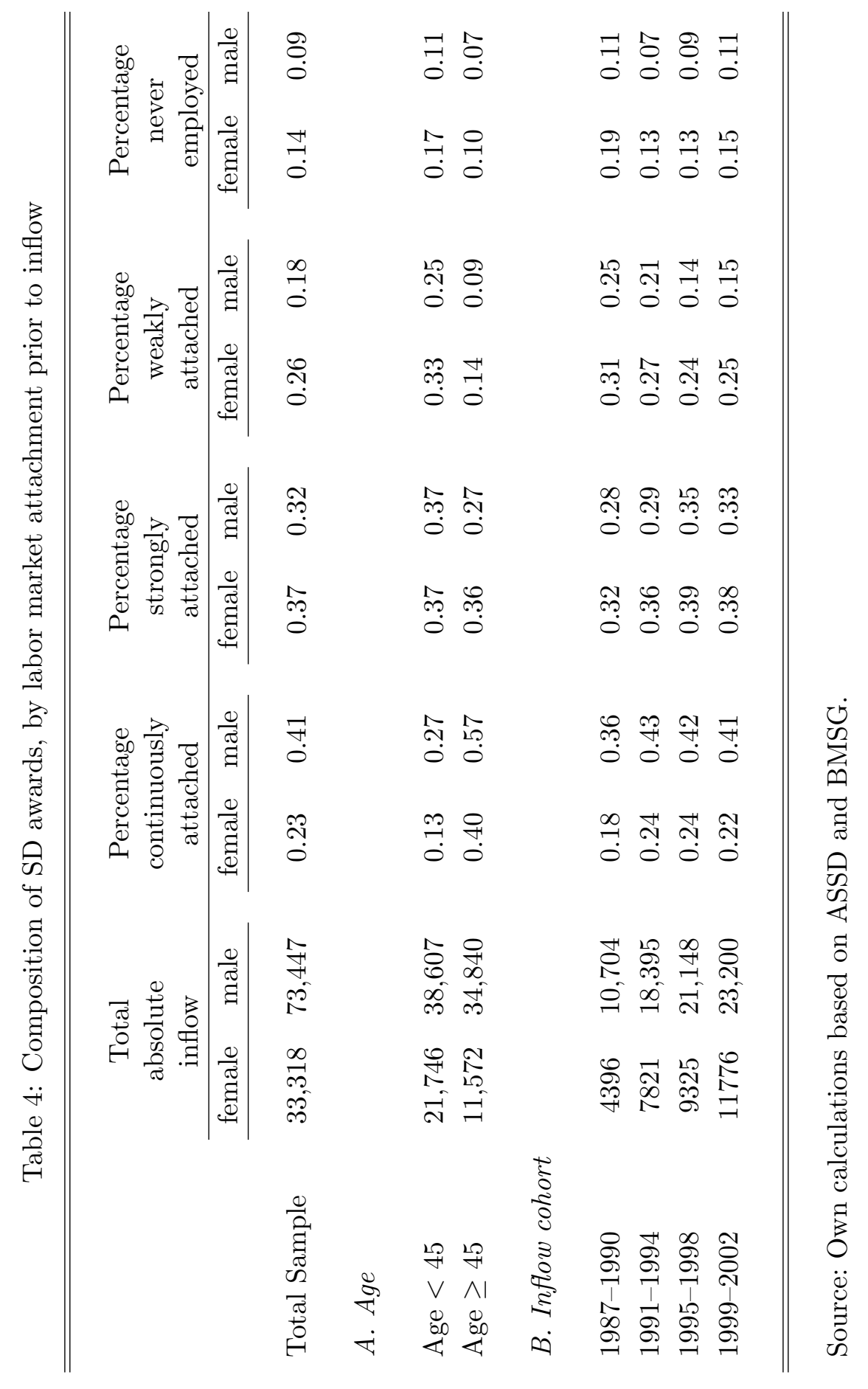




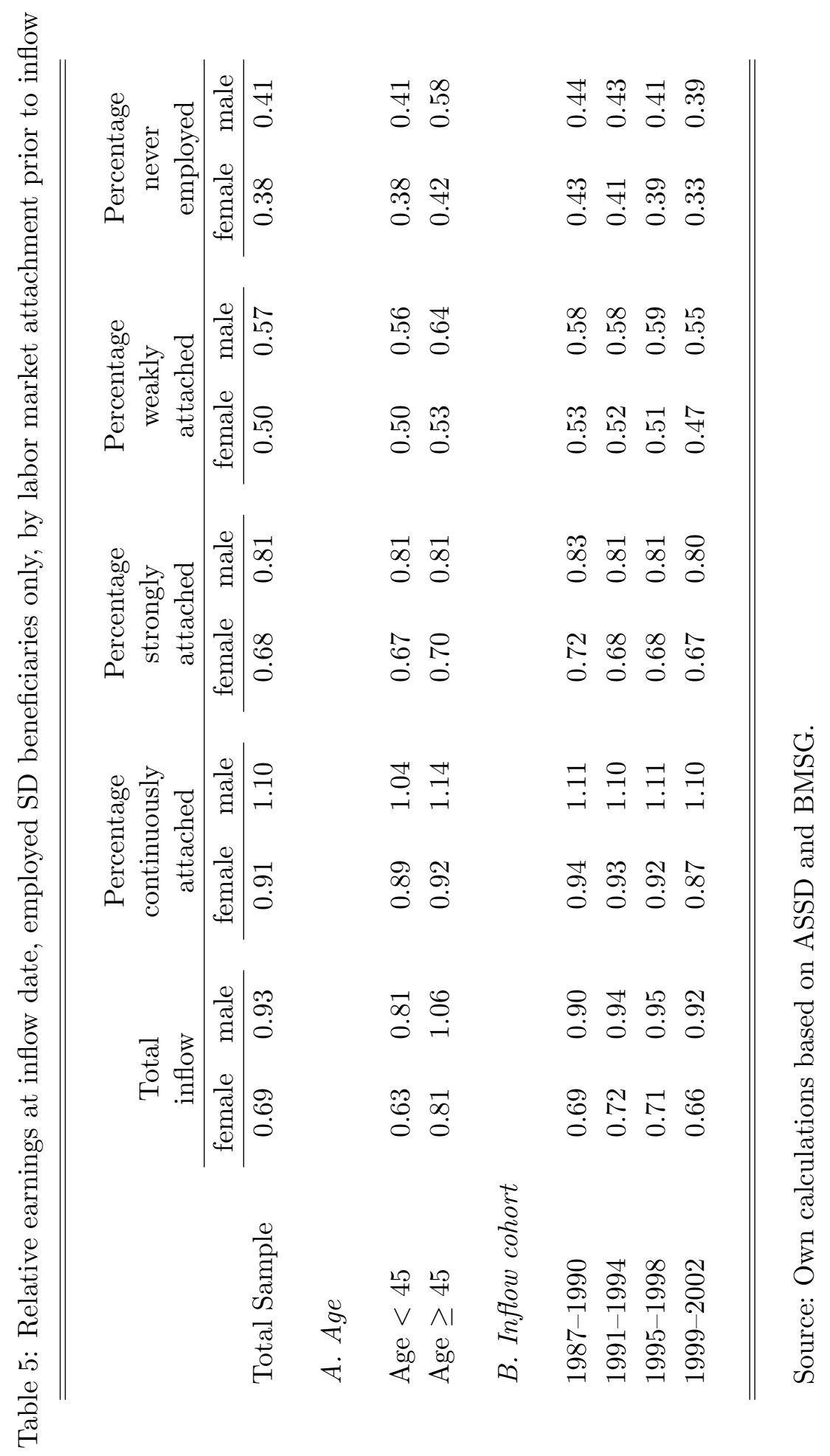


Table 6: The impact of SD-status on employment and relative earnings

\begin{tabular}{lccccc}
\hline \hline & \multicolumn{2}{c}{ OLS } & & \multicolumn{2}{c}{ Fixed effects } \\
& Employment & Relative earnings & & Employment & Relative earnings \\
\cline { 2 - 3 } \cline { 5 - 6 } SD-status & $-0.069^{\star \star \star}$ & $-0.0013^{\star \star \star}$ & & $-0.016^{\star \star \star}$ & $-0.030^{\star \star \star}$ \\
& $(0.001)$ & $(0.001)$ & & $(0.001)$ & $(0.002)$ \\
Controls & Yes & Yes & & Yes & Yes \\
Number of observations & $1,051,742$ & $1,051,742$ & & 632,232 & 632,232 \\
$\mathrm{R}^{2}$ & 0.089 & 0.134 & & 0.129 & 0.008 \\
F-Value & $5,527.172$ & $8,100.998$ & & $4,949.842$ & 241.389 \\
\hline \hline
\end{tabular}

Source: Own calculations based on ASSD and BMSG.

Standard errors in parentheses.

$\star \star \star,{ }^{\star \star},{ }^{\star}$ denotes significance at the $1 \%, 5 \%, 10 \%$ level respectively.

Controls include calendar year dummies, age, age ${ }^{2}$ and female dummy (in OLS regressions). 
Table 7: Heterogeneity of SD-effects by age and sex (fixed effects regressions)

\begin{tabular}{|c|c|c|c|c|}
\hline & \multicolumn{2}{|c|}{ Age $<45$} & \multicolumn{2}{|c|}{ Age $\geq 45$} \\
\hline & Women & Men & Women & Men \\
\hline \multicolumn{5}{|l|}{ Panel A: Employment } \\
\hline SD-status & $\begin{array}{c}0.040^{\star \star \star} \\
(0.003)\end{array}$ & $\begin{array}{c}-0.007^{\star \star \star} \\
(0.002)\end{array}$ & $\begin{array}{c}-0.047^{\star \star \star} \\
(0.004)\end{array}$ & $\begin{array}{c}-0.055^{\star \star \star} \\
(0.002)\end{array}$ \\
\hline Controls & Yes & Yes & Yes & Yes \\
\hline Number of observations & 212,925 & 390,159 & 110,601 & 338,057 \\
\hline $\mathrm{R}^{2}$ & 0.068 & 0.066 & 0.221 & 0.252 \\
\hline F-Value & 758.116 & $1,325.462$ & $1,494.922$ & $5,484.794$ \\
\hline \multicolumn{5}{|c|}{ Panel B: Relative earnings } \\
\hline SD-status & $\begin{array}{c}-0.032^{\star \star \star} \\
(0.005)\end{array}$ & $\begin{array}{l}-0.009^{\star} \\
(0.005)\end{array}$ & $\begin{array}{c}-0.046^{\star \star \star} \\
(0.002)\end{array}$ & $\begin{array}{c}-0.049^{\star \star \star} \\
(0.002)\end{array}$ \\
\hline Controls & Yes & Yes & Yes & Yes \\
\hline Number of observations & 123,272 & 248,025 & 62,810 & 198,125 \\
\hline $\mathrm{R}^{2}$ & 0.009 & 0.011 & 0.011 & 0.009 \\
\hline F-Value & 49,324 & 124.382 & 31.440 & 81.594 \\
\hline
\end{tabular}

Source: Own calculations based on ASSD and BMSG.

Standard errors in parentheses.

$\star \star \star,{ }^{\star \star},{ }^{\star}$ denotes significance at the $1 \%, 5 \%, 10 \%$ level respectively.

Controls include calendar year dummies, age and age ${ }^{2}$. 
Table 8: SD-effects on employment, by employment status at date of SD award (fixed effects regressions)

\begin{tabular}{|c|c|c|c|}
\hline & Total & Age $<45$ & Age $\geq 45$ \\
\hline \multicolumn{4}{|c|}{ Panel A: Employed at date of $S D$ award } \\
\hline SD-status & $\begin{array}{c}0.104^{\star \star \star} \\
(0.001)\end{array}$ & $\begin{array}{c}0.140^{\star \star \star} \\
(0.002)\end{array}$ & $\begin{array}{c}0.058^{\star \star \star} \\
(0.002)\end{array}$ \\
\hline Controls & Yes & Yes & Yes \\
\hline Number of observations & 744,580 & 418,348 & 326,232 \\
\hline $\mathrm{R}^{2}$ & 0.163 & 0.110 & 0.263 \\
\hline F-Value & $7,241.619$ & $2,501.531$ & $5,577.706$ \\
\hline \multicolumn{4}{|c|}{ Panel B: Unemployed or inactive at date of SD award } \\
\hline SD-status & $\begin{array}{c}-0.294^{\star \star \star} \\
(0.003)\end{array}$ & $\begin{array}{c}-0.252^{\star \star \star} \\
(0.004)\end{array}$ & $\begin{array}{c}-0.350^{\star \star \star} \\
(0.003)\end{array}$ \\
\hline Controls & Yes & Yes & Yes \\
\hline Number of observations & 307,162 & 184,736 & 122,426 \\
\hline $\mathrm{R}^{2}$ & 0.160 & 0.081 & 0.308 \\
\hline F-Value & $2,905.455$ & 786.878 & $2,614.831$ \\
\hline
\end{tabular}

Source: Own calculations based on ASSD and BMSG.

Standard errors in parentheses.

$\star \star \star,{ }^{\star \star},{ }^{\star}$ denotes significance at the $1 \%, 5 \%, 10 \%$ level respectively.

Controls include calendar year dummies, age and age $^{2}$. 
Table 9: SD-effects on relative earnings, by employment status at date of SD award (fixed effects regressions)

\begin{tabular}{|c|c|c|c|}
\hline & Total & Age $<45$ & Age $\geq 45$ \\
\hline \multicolumn{4}{|c|}{ Panel A: Employed at date of SD award } \\
\hline SD-status & $\begin{array}{c}-0.044^{\star \star \star} \\
(0.002)\end{array}$ & $\begin{array}{c}-0.030^{\star \star \star} \\
(0.003)\end{array}$ & $\begin{array}{c}-0.061^{\star \star \star} \\
(0.002)\end{array}$ \\
\hline Controls & Yes & Yes & Yes \\
\hline Number of observations & 546,644 & 313,577 & 233,067 \\
\hline $\mathrm{R}^{2}$ & 0.012 & 0.014 & 0.010 \\
\hline F-Value & 309.391 & 212.113 & 111.274 \\
\hline \multicolumn{4}{|c|}{ Panel B: Unemployed or inactive at date of SD award } \\
\hline SD-status & $\begin{array}{c}0.089^{\star \star \star} \\
(0.015)\end{array}$ & $\begin{array}{c}0.092^{\star \star \star} \\
(0.022)\end{array}$ & $\begin{array}{c}0.086^{\star \star \star} \\
(0.008)\end{array}$ \\
\hline Controls & Yes & Yes & Yes \\
\hline Number of observations & 85,588 & 57,720 & 27,868 \\
\hline $\mathrm{R}^{2}$ & 0.007 & 0.007 & 0.066 \\
\hline F-Value & 26.157 & 15.364 & 78.259 \\
\hline
\end{tabular}

Source: Own calculations based on ASSD and BMSG.

Standard errors in parentheses.

$\star \star \star, \star \star,{ }^{\star}$ denotes significance at the $1 \%, 5 \%, 10 \%$ level respectively. Controls include calendar year dummies, age and age $^{2}$. 
Table 10: Changes in SD-employment effects over time (fixed effects regressions)

\begin{tabular}{|c|c|c|c|}
\hline & Total & Age $<45$ & Age $\geq 45$ \\
\hline $\begin{array}{l}\text { SD-status } \\
\text { year 1991-1994 }\end{array}$ & $\begin{array}{c}0.000 \\
(0.002)\end{array}$ & $\begin{array}{c}0.009^{\star \star \star} \\
(0.002)\end{array}$ & $\begin{array}{c}-0.015^{\star \star \star} \\
(0.003)\end{array}$ \\
\hline $\begin{array}{l}\text { SD-status · } \\
\text { year 1995-1998 }\end{array}$ & $\begin{array}{c}-0.023^{\star \star \star} \\
(0.002)\end{array}$ & $\begin{array}{c}0.012^{\star \star \star} \\
(0.003)\end{array}$ & $\begin{array}{c}-0.062^{\star \star \star} \\
(0.002)\end{array}$ \\
\hline $\begin{array}{l}\text { SD-status · } \\
\text { year 1999-2002 }\end{array}$ & $\begin{array}{c}-0.045^{\star \star \star} \\
(0.002)\end{array}$ & $\begin{array}{l}0.011^{\star} \\
(0.003)\end{array}$ & $\begin{array}{c}-0.105^{\star \star \star} \\
(0.003)\end{array}$ \\
\hline Controls & Yes & Yes & Yes \\
\hline Number of observations & $1,051,742$ & 603,084 & 448,658 \\
\hline $\mathrm{R}^{2}$ & 0.134 & 0.066 & 0.245 \\
\hline F-Value & $7,312.942$ & $1,857.993$ & $6,282.02$ \\
\hline
\end{tabular}

Source: Own calculations based on ASSD and BMSG.

Standard errors in parentheses.

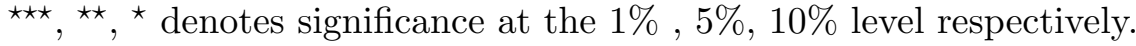
Controls include calendar year dummies, age and age ${ }^{2}$. 
Table 11: Changes in SD-relative earnings effects over time (fixed effects regressions)

\begin{tabular}{|c|c|c|c|}
\hline & Total & Age $<45$ & Age $\geq 45$ \\
\hline $\begin{array}{l}\text { SD-status } \\
\text { year 1991-1994 }\end{array}$ & $\begin{array}{c}-0.028^{\star \star \star} \\
(0.003)\end{array}$ & $\begin{array}{c}-0.014^{\star \star \star} \\
(0.005)\end{array}$ & $\begin{array}{c}-0.048^{\star \star \star} \\
(0.002)\end{array}$ \\
\hline $\begin{array}{l}\text { SD-status } \\
\text { year } 1995-1998\end{array}$ & $\begin{array}{c}-0.033^{\star \star \star} \\
(0.003)\end{array}$ & $\begin{array}{c}-0.018^{\star \star \star} \\
(0.005)\end{array}$ & $\begin{array}{c}-0.053^{\star \star \star} \\
(0.002)\end{array}$ \\
\hline $\begin{array}{l}\text { SD-status · } \\
\text { year 1999-2002 }\end{array}$ & $\begin{array}{l}-0.007^{\star} \\
(0.004)\end{array}$ & $\begin{array}{c}0.004 \\
(0.007)\end{array}$ & $\begin{array}{c}-0.027^{\star \star \star} \\
(0.003)\end{array}$ \\
\hline Controls & Yes & Yes & Yes \\
\hline Number of observations & 632,232 & 371,297 & 260,935 \\
\hline $\mathrm{R}^{2}$ & 0.008 & 0.010 & 0.008 \\
\hline F-Value & 215.526 & 152.643 & 87.964 \\
\hline
\end{tabular}

Source: Own calculations based on ASSD and BMSG.

Standard errors in parentheses.

${ }^{\star \star \star},{ }^{\star \star},{ }^{\star}$ denotes significance at the $1 \%, 5 \%, 10 \%$ level respectively.

Controls include calendar year dummies, age and age ${ }^{2}$. 
Table A.1: Median daily earnings of blue-- and white-collar male workers (€), 1987-2005

\begin{tabular}{lc}
\hline \hline $\begin{array}{l}\text { Calendar } \\
\text { year }\end{array}$ & $\begin{array}{c}\text { Median } \\
\text { daily earnings }\end{array}$ \\
\hline 1987 & 46.17 \\
1988 & 47.57 \\
1989 & 53.10 \\
1991 & 56.48 \\
1992 & 59.36 \\
1993 & 61.71 \\
1994 & 63.54 \\
1995 & 65.51 \\
1996 & 66.54 \\
1997 & 67.30 \\
1998 & 68.60 \\
1999 & 70.31 \\
2000 & 70.74 \\
2001 & 72.44 \\
2002 & 74.71 \\
\hline \hline
\end{tabular}

Source: Own calculations based on ASSD and BMSG. 
Table A.2: The impact of SD-status on employment (OLS Regression, estimates of all variables)

\begin{tabular}{|c|c|}
\hline & Employment \\
\hline SD-status & $\begin{array}{c}-0.069^{\star \star \star} \\
(0.001)\end{array}$ \\
\hline Year 1988 & $\begin{array}{c}0.080^{\star \star \star} \\
(0.003)\end{array}$ \\
\hline Year 1989 & $\begin{array}{c}0.093^{\star \star \star} \\
(0.003)\end{array}$ \\
\hline Year 1990 & $\begin{array}{c}0.105^{\star \star \star} \\
(0.003)\end{array}$ \\
\hline Year 1991 & $\begin{array}{c}0.107^{\star \star \star} \\
(0.002)\end{array}$ \\
\hline Year 1992 & $\begin{array}{c}0.101^{\star \star \star} \\
(0.002)\end{array}$ \\
\hline Year 1993 & $\begin{array}{c}0.082^{\star \star \star} \\
(0.002)\end{array}$ \\
\hline Year 1994 & $\begin{array}{c}0.073^{\star \star \star} \\
(0.002)\end{array}$ \\
\hline Year 1995 & $\begin{array}{c}0.057^{\star \star \star} \\
(0.002)\end{array}$ \\
\hline Year 1996 & $\begin{array}{c}0.033^{\star \star \star} \\
(0.002)\end{array}$ \\
\hline Year 1997 & $\begin{array}{c}0.017^{\star \star \star} \\
(0.002)\end{array}$ \\
\hline Year 1998 & $\begin{array}{c}0.013^{\star \star \star} \\
(0.002)\end{array}$ \\
\hline Year 1999 & $\begin{array}{c}0.009^{\star \star \star} \\
(0.002)\end{array}$ \\
\hline Year 2000 & $\begin{array}{c}-0.001 \\
(0.002)\end{array}$ \\
\hline Year 2001 & $\begin{array}{c}-0.007^{\star \star \star} \\
(0.003)\end{array}$ \\
\hline Year 2002 & $\begin{array}{c}-0.016^{\star \star \star} \\
(0.003)\end{array}$ \\
\hline Age & $\begin{array}{c}0.059^{\star \star \star} \\
(0.000)\end{array}$ \\
\hline $\operatorname{Age}^{2}$ & $\begin{array}{c}-0.001^{\star \star \star} \\
(0.000)\end{array}$ \\
\hline Female dummy & $\begin{array}{c}-0.067^{\star \star \star} \\
(0.001)\end{array}$ \\
\hline Constant & $\begin{array}{c}-0.396^{\star \star \star} \\
(0.004)\end{array}$ \\
\hline Number of observations & $1,051,742$ \\
\hline $\mathrm{R}^{2}$ & 0.089 \\
\hline F-Value & $5,527.172$ \\
\hline
\end{tabular}

Source: Own calculations based on ASSD and BMSG.

Standard errors in parentheses.

${ }^{\star \star \star},{ }^{\star \star},{ }^{\star}$ denotes significance at the $1 \%, 5 \%, 10 \%$ level respectively. 
Table A.3: The impact of SD-status on relative earnings (OLS Regression, estimates of all variables)

\begin{tabular}{|c|c|}
\hline & Relative earnings \\
\hline SD-status & $\begin{array}{c}-0.016^{\star \star \star} \\
(0.001)\end{array}$ \\
\hline Year 1988 & $\begin{array}{c}-0.023^{\star \star \star} \\
(0.004)\end{array}$ \\
\hline Year 1989 & $\begin{array}{c}-0.028^{\star \star \star} \\
(0.004)\end{array}$ \\
\hline Year 1990 & $\begin{array}{c}-0.045^{\star \star \star} \\
(0.004)\end{array}$ \\
\hline Year 1991 & $\begin{array}{c}-0.054^{\star \star \star} \\
(0.003)\end{array}$ \\
\hline Year 1992 & $\begin{array}{c}-0.061^{\star \star \star} \\
(0.003)\end{array}$ \\
\hline Year 1993 & $\begin{array}{c}-0.060^{\star \star \star} \\
(0.003)\end{array}$ \\
\hline Year 1994 & $\begin{array}{c}-0.058^{\star \star \star} \\
(0.003)\end{array}$ \\
\hline Year 1995 & $\begin{array}{c}-0.056^{\star \star \star} \\
(0.003)\end{array}$ \\
\hline Year 1996 & $\begin{array}{c}-0.052^{\star \star \star} \\
(0.003)\end{array}$ \\
\hline Year 1997 & $\begin{array}{c}-0.054^{\star \star \star} \\
(0.003)\end{array}$ \\
\hline Year 1998 & $\begin{array}{c}-0.062^{\star \star \star} \\
(0.003)\end{array}$ \\
\hline Year 1999 & $\begin{array}{c}-0.080^{\star \star \star} \\
(0.004)\end{array}$ \\
\hline Year 2000 & $\begin{array}{c}-0.059^{\star \star \star} \\
(0.004)\end{array}$ \\
\hline Year 2001 & $\begin{array}{c}-0.085^{\star \star \star} \\
(0.004)\end{array}$ \\
\hline Year 2002 & $\begin{array}{c}-0.094^{\star \star \star} \\
(0.004)\end{array}$ \\
\hline Age & $\begin{array}{c}0.039^{\star \star \star} \\
(0.000)\end{array}$ \\
\hline $\operatorname{Age}^{2}$ & $\begin{array}{c}0.000^{\star \star \star} \\
(0.000)\end{array}$ \\
\hline Female dummy & $\begin{array}{c}-0.212^{\star \star \star} \\
(0.001)\end{array}$ \\
\hline Constant & $\begin{array}{l}0.016^{\star} \\
(0.008)\end{array}$ \\
\hline Number of observations & 632,232 \\
\hline $\mathrm{R}^{2}$ & 0.129 \\
\hline F-Value & $4,949.842$ \\
\hline
\end{tabular}

Source: Own calculations based on ASSD and BMSG.

Standard errors in parentheses.

${ }^{\star \star \star},{ }^{\star \star},{ }^{\star}$ denotes significance at the $1 \%, 5 \%, 10 \%$ level respectively. 